\title{
Private Equity Ownership and Financial Misreporting
}

\author{
Shuyang Wang \\ Northeastern University \\ s.wang@northeastern.edu
}

July 2020

I am grateful to members of my dissertation committee, Laura Yue Li (chair), Clara Chen, Jeremy McClane, and Wei Zhu for guidance and comments. I thank Rashad Abdel-Khalik, Nerissa Brown, Ciao-Wei Chen, Fei Du, Kai Du, Hans Frimor, Kamber Hetrick, Udi Hoitash, David Koo, Ganesh Krishnamoorthy, Jing Liu, Mark Peecher, Jay Ritter, Theodore Sougiannis, Anne Thompson, Anh Vuong, and Summer Xiao for helpful comments. I also thank workshop participants at the University of Illinois at Urbana-Champaign, CKGSB, University of Southern Denmark, Northeastern University, conference participants at 2019 Impact the Future Conference and 2019 AAA Midwest Region Meeting, and two anonymous reviewers. I acknowledge financial support from the D'Amore-McKim School of Business at Northeastern University and Gies College of Business at the University of Illinois at UrbanaChampaign. 


\title{
Private Equity Ownership and Financial Misreporting
}

\begin{abstract}
I study whether private equity (PE) ownership is associated with portfolio firms' financial misreporting by examining the occurrence of restatements and SEC enforcement actions during the post-IPO period. Using a sample of firms that went public between 1998 and 2015, I find that PE-backed firms are more likely to issue restatements during the five-year post-IPO period than non-PE-backed firms. The restatements received by PE-backed firms are more material, i.e., having a more negative impact on net income or longer duration. Furthermore, PE-backed firms are more likely to be subject to SEC Accounting and Auditing Enforcement Releases (AAERs). Cross-sectional analyses suggest that the financial misreporting of PE-backed firms is attributable to PE firms' pursuit of profits as well as their control over the board and executives. Overall, this paper provides new insights into the opportunistic influence of PE firms.
\end{abstract}

Keywords: Private equity, financial reporting quality, misreporting, corporate governance 


\section{Introduction}

The private equity (PE) industry has experienced substantial growth in recent years, reaching an all-time high of $\$ 4.11$ trillion in assets under management as of June 2019 (Preqin 2020). Although PE firms are often applauded for their high returns to investors, their impact on portfolio firms remains controversial. PE investment has preceded not only successful IPOs of portfolio firms ${ }^{1}$ such as Hilton Worldwide but also corporate failures and even bankruptcies, including Toys "R" Us and Payless ShoeSource. Recently, regulators have voiced concerns about the influence of PE and taken actions to restrict PE firms' manipulative behaviors. ${ }^{2,3}$ The rising popularity and debatable effect of PE investment in the U.S. market make it important to understand PE firms' impact on portfolio firms. In this paper, I study whether PE firms are associated with portfolio firms' financial misreporting by examining the occurrence of restatements and SEC enforcement actions during the post-IPO period.

It is ex-ante unclear whether PE-backed firms are more likely to engage in misreporting than non-PE-backed firms. On the one hand, prior studies suggest that PE ownership improves the corporate governance of portfolio firms, which may curb accounting manipulation and improve reporting quality. Specifically, PE-backed firms tend to receive superior monitoring by concentrated equity owners and debt holders (Kaplan and Strömberg 2009; Renneboog and

\footnotetext{
${ }^{1} \mathrm{PE}$ firms invest capital by conducting a buyout, i.e., taking controlling ownership and making portfolio firms go private. The buyout is usually facilitated by a large amount of debt. PE firms actively manage portfolio firms and seek exit options after three to six years. IPO is viewed as the best route for PE's exit.

${ }^{2}$ For example, U.S. Department of Justice (DOJ) issued a press release on February 23, 2018 about filing a complaint in intervention against Diabetic Care Rx LLC d/b/a Patient Care America (PCA) as well as Riordan, Lewis \& Haden Inc. (RLH), a PE firm that manages PCA, for the involvement in an alleged kickback scheme. The inclusion of a PE firm as a defendant in a False Claim Act lawsuit signals the willingness of DOJ to hold PE firms accountable for the noncompliance of their portfolio firms. Details of the lawsuit can be found at https://www. justice.gov/opa/pr/united-states-files-false-claims-act-complaint-against-compounding-pharmacy-private-equity. ${ }^{3}$ Together with Democratic co-sponsors, U.S. presidential candidate Elizabeth Warren has introduced "The Wall Street Looting Act of 2019" in Congress to reform the PE industry. Details of the bill can be found at https://www.congress.gov/bill/116th-congress/senate-bill/2155.
} 
Vansteenkiste 2017). PE-backed firms have mitigated conflict of interests between management and shareholders thanks to better aligned managerial incentives (Jensen 1989; Leslie and Oyer 2009; Masulis and Thomas 2009; Jackson 2013). Moreover, as repeated players in the market, PE firms face reputational concerns that potentially dominate manipulative incentives (Katz 2009; Demiroglu and James 2010; Ivashina and Kovner 2011; Huang et al. 2016). Lastly, due to debt added during buyout, the management of portfolio firms commits to future cash flows by making less suboptimal investments (Jensen 1989; Bhagat et al. 1990), reducing the need to cover up poor performance.

On the other hand, PE-backed firms face unique governance challenges, which may increase the financial misreporting of portfolio firms. First, PE firms have a relatively restrictive window to exit the portfolio firms after an IPO,${ }^{4}$ and contracts between PE firms and their investors provide strong incentives to shorten investment horizons (Rappaport 1990; Phalippou 2009; Metrick and Yasuda 2011). The pursuit of profits incentivizes financial reporting manipulations that can inflate the stock price of the portfolio firms and maximize returns from equity exit (Cao and Lerner 2009; Cao 2011). Second, PE firms possess controlling power in portfolio firms and actively participate in portfolio firms' board selection, executive appointment, compensation design, strategic and operational decisions, budgeting, and earnings issues (Cotter and Peck 2001; Kosman 2009; Leslie and Oyer 2009; Metrick and Yasuda 2011; Jackson 2013). ${ }^{5}$ Such active and controlling stakes may put executives under high pressure to engage in manipulative reporting that benefits PE firms. The dominant power of PE firms on the

\footnotetext{
${ }^{4}$ On average, it takes three years for PE firms to exit from portfolio firms after the IPO.

${ }^{5}$ In my sample, PE firms on average hold 41 percent of the common shares in portfolio firms after the IPO before the exit.
} 
board may also weaken the board's willingness and ability to monitor or prevent misreporting effectively.

The evidence on how PE firms influence portfolio firms' accounting practices is scarce (Holthausen and Larcker 1996; Chou et al. 2006; Katz 2009). This is because little data is available once a portfolio firm goes private through a leveraged buyout, and detailed data on cash inflows and outflows of PE firms' investments are mostly proprietary and extremely difficult to obtain (Brown et al. 2015). I focus on IPO firms as post-IPO data enable me to observe the outcomes of PE firms' private investment. ${ }^{6}$ Moreover, IPO is viewed as the best exit option as it provides the highest returns among the three common exit channels (Masulis and Thomas 2009) and is best aligned with PE firms' interests.

I collect IPO and PE ownership information from SDC Platinum, VentureXpert, and SEC EDGAR, restatement data from Audit Analytics, and SEC Accounting and Auditing Enforcement Releases (AAERs) from the SEC's website. My sample consists of firms that went public between 1998 and 2015, a total of 3,146 firm-years after requiring necessary control variables of firm characteristics. Using an entropy-balanced sample, I find that during the fiveyear post-IPO period, PE-backed firms are more likely than non-PE-backed firms to receive material restatements (i.e., restatements with a more negative impact on net income or a longer restated period). Furthermore, PE-backed firms are more likely to be subject to AAERs. I also find that the propensity of financial misreporting in PE-backed firms is only significantly greater than non-PE-backed firms during periods when PE firms still hold controlling ownership.

\footnotetext{
${ }^{6} \mathrm{PE}$ firms' exit strategies can be classified into three categories: secondary buyout, in which the portfolio firm is sold to another PE firm; trade sale, in which the portfolio firm is acquired by or merged with another firm; and IPO, in which the portfolio firm goes public. Portfolio firms may remain private if PE firms exit through trade sale or secondary buyout.
} 
Further analyses suggest that the increased likelihood of material restatements and AAERs of PE-backed firms is driven by intentional misreporting to the benefit of PE firms. First, I find that PE-backed firms are more likely to commit egregious misreporting during periods when they dispose of ownership to a larger extent, consistent with reporting manipulation to increase PE firms' returns upon exit. Second, PE-backed firms are more likely to receive material restatements or AAERs when PE firms hold larger ownership in portfolio firms, and the restated period is longer when PE firms are larger. Further, PE-backed firms are more likely to have a voting disagreement with proxy advisers, and the management is more likely to win the voting when there is a divergence of voting recommendation. The evidence is consistent with the pressure of financial reporting manipulation and impaired board monitoring due to the power of PE firms.

I also investigate whether the increased likelihood of getting material restatements or AAERs for PE-backed firms reflects intensified regulatory scrutiny. Conditional on receiving a restatement, PE-backed firms are not different from non-PE-backed firms in facing subsequent securities class actions or SEC investigations, indicating that the higher frequencies of restatements, material restatements, and AAERs are not attributable to heightened regulatory attention.

I use various methods to address the possibility that PE-backed firms might be systematically different from non-PE-backed firms. Besides the entropy balancing adopted in the main regressions, I use the Heckman (1979) model and an instrumental variable, i.e., the portion of IPO firms having PE ownership in the same industry and IPO year of the portfolio firm, to account for PE firms' endogenous selection of portfolio firms. The results are similar to the main analysis. 
This paper makes several contributions. First, this paper unveils the negative role of PE ownership in the financial reporting quality of portfolio firms given the unprecedented growth in the PE industry and the contention over PE firms' impact. I find that PE-backed IPO firms are more likely to engage in manipulative reporting than non-PE-backed firms. This finding supports the opportunistic view that PE firms extract profits at the cost of portfolio firms' shareholders (Degeorge and Zeckhauser 1993; Cao 2011).

Second, this study adds to the literature that offers mixed findings on the influence of PE firms on portfolio firms' corporate governance (Kaplan and Strömberg 2009; Masulis and Thomas 2009). My findings suggest that the pursuit of profits by PE firms gives rise to the misstatement of financial performance before PE firms' exit; moreover, PE firms' significant influence over the board and executives weakens the monitoring of portfolio firms. These results highlight the negative impact of PE firms on portfolio firms' corporate governance.

Further, the paper contributes to the literature that explores the relationship between ownership structure and financial misreporting (Larcker et al. 2007; Burns et al. 2010; Dou et al. 2016). As prior studies debate over whether large shareholders improve financial reporting quality through monitoring or deteriorate financial reporting quality by exploiting other shareholders, my paper adds to the argument by showing that PE ownership is associated with more egregious misreporting in portfolio firms.

My findings are of interest to multiple groups of stakeholders, including investors, debt holders, and auditors of PE-backed firms, investors of PE firms and fund of funds, and regulators of the PE industry. The evidence suggests that the manipulative reporting of PE-backed firms is related to the size of PE firms and the timing of ownership disposal after IPO, investors should be wary of PE investments with these characteristics. Auditors should also be aware of the 
heightened audit risks, and regulators may consider enhancing monitoring on the PE industry and establishing a more effective regulatory framework.

The paper proceeds as follows. Section 2 reviews the literature and develops the hypothesis. Section 3 describes the research design and sample selection. Section 4 presents the empirical results. Section 5 concludes.

\section{Literature Review and Hypothesis Development}

\subsection{Institutional background}

PE market is growing at a fast speed in recent years. The market raised funds of $\$ 593.7$ billion globally in 2018, and assets under management increased by $15 \%$ from 2018 and reached a remarkable record of $\$ 4.11$ trillion in 2019 (Preqin 2019, 2020). Buyout funds continue to outperform public equity and meet investor expectations (Preqin 2018). ${ }^{7}$ Over the past two decades, PE-backed IPOs count as $20 \%$ of all IPOs and have a presence in all industries.

$\mathrm{PE}$ is a form of alternative investment with capital not listed on the public market. A typical PE fund under a PE firm has a life cycle of about ten years, during which general partners (GPs) screen investment opportunities, conduct the buyout, and actively manage portfolio firms. ${ }^{8}$ When GPs observe a potentially satisfactory rate of return, PE firms will exit from the portfolio

\footnotetext{
${ }^{7}$ As the PE market offers attractive prospects, investors are willing to invest more capital and increase allocation to $\mathrm{PE}$ in the long term. There are at least 15,000 firms spanning all industries owned by PE firms, with a total net value of over \$1.8 trillion. PE-backed firms are estimated to hire over 20 million people globally at the end of 2017 . In the U.S., millions of people have pensions invested in private funds, and the activities of PE-backed firms are estimated to generate 5\% of GDP (Ernst \& Young 2018).

${ }^{8}$ After the establishment of a PE fund, GPs identify potential investment opportunities, conduct due diligence, and negotiate terms with different parties. GPs then close the deal by buying firms with the capital provided by limited partners (LPs) and loans secured by assets and expected cash flows of portfolio firms. PE firms often engage in buyouts of public firms, which results in delisting. Going private shields portfolio firms from market sentiment and regulatory compliance, and PE firms can focus on value reengineering through effective internal communications.
} 
firms to obtain returns on investment. The average holding time for a buyout takes about five years before the exit of PE firms.

Figure 1 illustrates the timeline of PE investment in a portfolio firm. Olympus Partners conducted the buyout of Symmetry Medical Inc. on October 18, 2000 and completed the IPO on December 8, 2004. Two years after the IPO, GPs from Olympus Partners resigned from the board and Olympus Partners fully exited from Symmetry Medical Inc by selling its holdings. ${ }^{9}$

[Insert Figure 1 here]

PE firms are different from traditional institutional investors, such as pension funds, mutual funds, and hedge funds. Before the investment exit, portfolio firms of PE firms stay private and have little public information. Portfolio values are not marked to market, and huge information asymmetry exists in PE investment. Other institutional investors invest mostly in publicly traded assets with greater liquidity and less information asymmetry. More importantly, PE firms actively control and manage portfolio firms, whereas other institutional investors have little opportunity to involve in decision-making in portfolio firms directly. ${ }^{10}$ Furthermore, PE firms have a finite investment horizon and need to achieve investment returns by focusing on a clear exit strategy (Metrick and Yasuda 2011).

\footnotetext{
${ }^{9} \mathrm{PE}$ firms are often criticized for unnecessary market expansions and aggressive cost-cutting strategies to achieve good performance, which increases the likelihood of manipulations beyond GAAP and subsequent restatements. Symmetry Medical Inc. announced a restatement on 10/4/2007, shortly after Olympus Partners' exit. The restated period was from 1/1/2005 to 6/30/2007, during part of which Olympus Partners still held controlling power of the firm. Symmetry Medical Inc received an AAER in 1/30/2012 regarding its material overstatement of revenue and assets and understatement of expenses of its subsidiary.

${ }^{10}$ Unlike PE firms with controlling ownership, other institutional owners usually take the minority interest in portfolio firms. Some people may argue that activist hedge funds also structure as limited partnerships, appeal to accredited investors, face fewer regulations, possess similar owner mentality, and focus on replacing the entrenched board and conducting operational changes. For example, Cheng et al. (2015) find that hedge fund activists provide close monitoring and demand higher financial reporting quality, resulting in higher conditional accounting conservatism of target firms. Nevertheless, for the activist hedge funds to conduct any change within portfolio firms, they face the defensive tactics and need to convince other shareholders.
} 
Venture capital (VC) is another type of private capital investor, but it is distinct from PE. VC firms invest in minority positions to grow portfolio firms from startups, whereas PE firms tend to take controlling ownership on mature and profitable firms. In contrast to PE firms that add a large amount of debt to portfolio firms, VC firms do not necessarily use debt financing. ${ }^{11,12}$

\subsection{The positive impact of PE ownership}

Prior studies suggest that PE firms generate value in various ways. They conduct financial, operational, and governance value reengineering to portfolio firms (Kaplan and Strömberg 2009), and increase free cash flow, EBITDA/earnings growth, and market multiple (Folus and Boutron 2015). PE-backed firms avoid costs associated with listing on the public market, enhance value through experts' daily involvement of operating activities, and improve monitoring from concentrated ownership and debtholders (Renneboog and Vansteenkiste 2017). Concentrated ownership in PE-backed firms mitigates information asymmetries (Wruck 1989).

Furthermore, PE firms enhance board monitoring by taking multiple or even majority board positions in portfolio firms (Cotter and Peck 2001). These directors from PE firms tend to have stronger financial skills and experience through prior buyouts compared with directors in public firms without PE presence. PE firms also improve corporate governance of portfolio firms by replacing ineffective and entrenched executives with more talented managers (Kaplan and Strömberg 2009). Underperformed managers in PE-backed firms are likely to be dismissed. ${ }^{13}$

\footnotetext{
${ }^{11}$ Because VC-backed deals may contain multiple rounds of investment and divestment, focusing on PE-backed deals provides an easier way to observe PE entry and exit.

${ }^{12}$ Prior literature provides mixed findings on the impact of $\mathrm{VC}$ firms on portfolio firms. The certification hypothesis suggests that VC firms, as repeated players in the market, lead to IPOs with high-quality auditors and underwriters (Megginson and Weiss 1991). On the contrary, the grandstanding hypothesis suggests that VC firms time the market and take portfolio firms public prematurely (Gompers 1996; Lee and Wahal 2004).

${ }^{13}$ A survey conducted by Alix Partners in 2017 reveals that 58\% of the CEOs in portfolio firms are fired within two years of a buyout. $73 \%$ of the CEOs in portfolio firms are replaced during the funds' investment life cycle. See https://www.alixpartners.com/media/12276/s042583.pdf.
} 
In addition, PE firms provide management in portfolio firms with more equity-based compensation contracts, which better aligns the incentives of management to shareholders and alleviates agency problems (Leslie and Oyer 2009; Jackson 2013). The incentive is further strengthened by the increased sensitivity of stock price to performance due to high leverage. Leslie and Oyer (2009) find that PE-owned firms provide twice as much as equity-based compensation and more cash compensation than comparable public companies. Jackson (2013) finds that directors appointed by PE firms, with stronger motivation to maximize shareholder value, offer higher pay-for-performance in executive compensation contracts. Bloom et al. (2015) suggest that PE-backed firms are well managed in terms of performance monitoring, effective targets, and performance incentives using a survey of over 15,000 interviews in over 10,000 manufacturing plants across 34 countries.

As repeated players in the leveraged buyout (LBO) market, PE firms have reputational concerns for debt financing and future fundraising. More reputable PE firms pay narrower loan spreads, have longer loan maturities, and more relaxed covenant structure (Demiroglu and James 2010; Ivashina and Kovner 2011). Huang et al. (2016) use bond yield spread data to show that PE firms' reputational concerns dominate their incentives to exploit other stakeholders such as bondholders. LPs of PE firms, who are often large public pension funds and wealthy individuals, care about PE firms' performance and impact due to social and political concerns. To protect reputation, PE firms may not want portfolio firms to engage in manipulative behaviors that would cause future fundraising issues.

PE firms often lever up the capital structure of portfolio firms, which commits management to future cash flows, reduces the likelihood of making a suboptimal investment and 
free cash flow problems (Jensen 1989; Bhagat et al. 1990), and provides more tax benefits than management-owned firms (Badertscher et al. 2013).

Based on the above reasons that PE firms improve corporate governance, prior studies document that PE-backed firms improve profitability, operating performance, and stock performance. ${ }^{14}$ Driven by improved corporate governance, PE-backed firms are also found to have higher earnings quality. Using a sample of firms with privately-held equity and publicly traded debt, Katz (2009) finds that PE-backed firms have lower abnormal accruals and industryadjusted growth in net operating assets and have a higher frequency of timely loss recognition.

\subsection{The negative impact of PE ownership}

Prior literature attributes the opportunistic behaviors by PE firms to their limited investment horizons and the ultimate goal of extracting profits by selling shares of portfolio firms (Rappaport 1990; Phalippou 2009; Metrick and Yasuda 2011). Phalippou (2009) documents PE firms' inclination to time the investment exits and cash flow distributions to maximize their profits. PE firms tend to liquidate good investments early and postpone the exit of poorly performing investments to boost the carried interest. PE firms distribute large payments early to investors to increase the internal rate of return. Contracts in the PE firms often contain provisions that encourage early investment exits so that PE firms can reinvest the capital and increase assets under management as well as management fees.

\footnotetext{
14 PE-backed IPOs exhibit improved profitability (Muscarella and Vetsuypens 1990; Degeorge and Zeckhauser 1993; Holthausen and Larcker 1996; Levis 2011) and positive abnormal returns (Mian and Rosenfeld 1993; Cao and Lerner 2009). Using deal-level data, Acharya et al. (2013) find the positive abnormal performance of PE firms is related to improving sales and operating margin of portfolio firms during the private phase. Davis et al. (2014) find that LBOs increase firm-level productivity by growing productive plants and reducing unproductive plants. With tax return data, Cohn et al. (2014) observe improvement in operating performance for PE-backed firms with public financial statements. Bernstein and Sheen (2016) find significant operational improvements for chain-owned restaurants than franchised restaurants due to the influence of PE owners.
} 
The agency costs of PE-backed firms stem from conflicts of interests not only between management and shareholders but also between controlling and minority shareholders. As controlling shareholders, PE firms have incentives to exploit minority shareholders of portfolio firms (Shleifer and Vishny 1997). For example, PE firms, after loading portfolio firms with an excessive amount of debt that may lead to bankruptcies, often have guaranteed return extracted from portfolio firms through collecting transaction fees. ${ }^{15} \mathrm{PE}$ firms engage in dividend recapitalization to extract profits rather than reinvest enough money to improve business, which starves portfolio firms of capital (Kosman 2009).

Besides exploiting the shareholders in the portfolio firms, PE firms have incentives to deceive LPs with opaque fee contracts. It is difficult for LPs to monitor PE firms or discover misconduct due to LPs' limited information, low chances to express their voices, and constraints to withdraw investment (Magnuson 2017). ${ }^{16}$ The minimal governance provided by LPs exacerbates PE firms' incentives to extract profits and manipulate.

As PE firms emphasize investment returns, they may encourage misreporting in portfolio firms to maximize the profits before the investment exits. ${ }^{17}$ I categorize the potential

\footnotetext{
${ }^{15}$ For example, Simmons Bedding Company filed bankruptcy in 2009. Investors lost millions of dollars, and thousands of employees got laid off. While at the same time, Thomas H. Lee Partners, the PE firm that invested in Simmons since 2003, made $\$ 77$ million in profit through special dividends. The former CEO of Simmons, Robert Hellyer, was asked to leave the company by PE firm and said, "From my experience, none of the private equity firms were building a brand for the future. Plus, the mind-set was, since the money was practically free, why not leverage the company to the maximum?" See https://www.nytimes.com/2009/10/05/business/economy/ 05simmons.html. Another example is the criticism faced by PE firms against the recent bankruptcy of Toys"R"Us and Payless ShoeSource. Taking a large amount of debt makes PE-backed firms difficult to adapt to industry changes. See https://theweek.com/articles/761124/how-vulture-capitalists-ate-toys-r, https://www. washingtonpost.com/business/2019/07/24/private-equitys-role-retail-has-decimated-million-jobs-study-says/, and https://www.theatlantic.com/magazine/archive/2018/07/toys-r-us-bankruptcy-private-equity/561758/.

${ }^{16}$ As opposed to public equity investors, LPs have little ability to govern how GPs manage the fund. LPs typically have no voting rights on the sale of portfolio firms, the compensation of GPs, and the assignment of the board of directors of PE firms. LPs cannot sell or transfer the investment in a timely fashion once they commit the capital to PE firms. LPs receive barebones information from GPs and are restricted from sharing information with other LPs. ${ }^{17}$ An example is Abry Partners V, L.P. v. F\&W Acquis. LLC, in which Abry Partners, the acquiror, sued Providence Equity Partners as well as F\&W Acquisition, LLC, the sellers, for the misrepresentation of the financial
} 
misreporting caused by PE firms' incentives to dispose of ownership in portfolio firms due to the finite fund life and the goal to achieve a high return on investments as the "pursuit of profits" channel. ${ }^{18}$

In addition to chasing returns, PE firms control the board and executives and even collude with portfolio firms. By putting people on board, PE firms have a significant influence on portfolio firms' policies, including financial reporting decisions (Metrick and Yasuda 2011). PE firms possess dominant power to assign desirable top executives who may not have much industry experience but can facilitate future IPO. PE firms also offer attractive employment agreements for current executives to align their interests (Kosman 2009).

Target firms in buyout deals may collude with PE firms by offering PE bidders a bargain price (In re Topps Shareholders Litigation 2007; Kosman 2009; Dahl v. Bain Capital Partners, LLC 2013) or making selective disclosures before buyout to depress stock price (Masulis and Thomas 2009). Ertimur et al. (2014) find that managers of portfolio firms delay bad news during the quarter of IPO lockup expiration date so that the pre-IPO shareholders can sell shares at higher prices. When PE firms control the board of portfolio firms, the chances of financial misreporting to the benefit of PE firms significantly increase. I categorize the potential misreporting caused by PE firms' dominant power on the board of portfolio firms as the "captured board and executives" channel.

Overall, PE firms have wealth expropriation incentives given their limited investment horizons. PE firms are able to control the board and the management of portfolio firms to inflate

\footnotetext{
statements of the portfolio firm sold in the acquisition. The portfolio firm reported inflated revenues prior to the acquisition due to channel stuffing, early revenue recognition, and delayed expense recognition.

${ }^{18}$ More evidence suggests that PE firms do not improve governance of portfolio firms, but profit by buying undervalued firms and use market timing to push firms to go public (Degeorge and Zeckhauser (1993); Chou et al. 2006; Cao and Lerne 2009; Guo et al. 2011). The incentives to time the market come from PE firms' compensation structures and their pursuit of profits.
} 
prices before the exit at the cost of shareholders. Management in portfolio firms has incentives to boost short-term earnings through manipulations given the pressure to meet interest payments (DeFond and Jiambalvo 1994) and compensation targets (Leslie and Oyer 2009; Jackson 2013), and achieve high returns for PE firms. Because prior studies provide mixed evidence on the impact of PE ownership, I state the hypothesis in the null form:

H1: The likelihood of financial misreporting is not different between PE-backed firms and non-PE-backed firms after the IPO.

\section{Research Design and Sample Selection}

\subsection{Financial misreporting measures}

I adopt restatement as the first measure of financial misreporting. Restatements are directly related to corporate governance (Larcker et al. 2007) and earnings management incentives (Efendi et al. 2007). Restatements negatively affect firm value (Palmrose et al. 2004; Gleason et al. 2008; Hennes et al. 2008) and lead to litigations and management turnover (Palmrose and Scholz 2004; Hennes et al. 2008). As an external indicator of financial reporting quality, restatement has a lower Type I error rate in misstatement identifications.

I adopt material restatement as the second measure of financial misreporting. When PEbacked firms manipulate financial reporting, the misstatements may pile up to a larger extent before they get discovered. First, auditors may rely on monitoring from PE firms or debtholders if they know PE firms have reputation concerns and provide potentially better corporate governance. Second, experts in PE firms may have stronger abilities to hide manipulations before they exit and even collude with the management of portfolio firms. The power that they possess over management enables them to put management on a slippery slope of manipulation. 
Nevertheless, reputational concerns of PE firms and monitoring from PE firms and debtholders may deter financial misreporting in a timely fashion.

While restatement or its materiality may not necessarily reflect management intent (Hennes et al. 2008), I further adopt SEC enforcement as the third measure of financial misreporting. SEC enforcement actions can lead to a drop in firm value (Feroz et al. 1991; Dechow et al. 1996) and increased CEO turnover (Beneish 1999; Karpoff et al. 2008). The AAER sample contains the most egregious misstatements, gets rid of model misspecification problems, and has lower Type I error rate in identifying misstatements than discretionary accruals or restatements.

The risks of receiving SEC enforcement can be reduced if PE-backed firms have better corporate governance than non-PE-backed firms through monitoring from concentrated equity owners and debt holders, strengthened managerial incentives, and PE firms' reputational concerns. Nevertheless, high leverage and performance-based compensation of portfolio firms not only increase management's pressure to report good performance but also exaggerate downside risks. The likelihood of receiving an AAER is higher when management uses misleading representations to boost stock prices and facilitate PE firms' exit. The high governance costs faced by PE-backed firms can lead to a drop in financial reporting quality and an increased likelihood of being investigated by the SEC.

Currently, there is no evidence regarding how PE firms affect the likelihood of getting an AAER of portfolio firms. Different from institutional owners who often serve as plaintiffs, PE firms actively work with and monitor portfolio firms by internal reporting and board meetings, taking more of a role as an insider and defendant in the lawsuits.

\subsection{Research design}


I use IPO firms to examine how misreporting varies with PE ownership. ${ }^{19}$ For each IPO firm, I include five years after IPO if available. I use entropy balancing to achieve covariate balance for PE-backed firm-years and non-PE-backed firm-years based on industry, IPO year, and firm characteristics. Entropy balancing mitigates the endogeneity concern that PE-backed firms are systematically different from non-PE-backed firms due to selection effect.

To test H1, I run the following logistic regression:

$$
\text { Restatement }_{i, t}=\alpha+\beta_{0} * P E_{i, t}+\sum_{j} \gamma_{j} * \text { Control }_{i, t}+\varepsilon_{i, t}
$$

where Restatement $t_{\text {.t }}$ refers to whether the financial statement of firm $i$ is subject to a restatement during year $t . P E_{i, t}$ equals 1 if firm $i$ is backed by a PE firm, and the PE firm still holds controlling power in firm $i$ during year $t$. I follow prior studies to incorporate control variables (Larcker et al. 2007; Katz 2009), including firm size (Size), market-to-book ratio (MTB), leverage (Lev), profitability (ROA), sales growth (SaleGr), capital expenditure (Capex), loss indicator (Loss), cash holdings (Cash), firm age (Age), number of years after IPO offering date $\left(I P O \_A g e\right)$, and audit quality $(B i g N)$. In addition, I control for external monitoring, including analyst coverage (NAnalyst) and institutional ownership (InstOwn). Following Dechow et al. (2011), I control for change in receivables $\left(C h \_R e s\right)$, change in inventory $\left(C h \_I n v\right)$, change in employees $\left(C h \_E m p\right)$, change in return on assets $\left(C h \_R O A\right)$, and change in cash sales $\left(C h \_C s\right)$. Detailed definitions are in Appendix A. I include 2-digit SIC industry fixed effects and IPO year fixed effects in the regression. All standard errors are clustered at the firm level. A positive $\beta_{0}$ would indicate that PE-backed firms have a higher likelihood of getting a restatement after IPO.

To speak to the materiality of the restatement, I run the following logistic regression:

\footnotetext{
${ }^{19}$ Although the lockup period usually expires 180 days after IPO, which gives PE firms the right to exit, PE firms often retain a large percentage of ownership well beyond the lockup expiration date (Cao 2011).
} 


$$
\text { Restate_Material }_{i, t}=\alpha+\beta_{0} * P E_{i, t}+\sum_{j} \gamma_{j} * \text { Control }_{i, t}+\varepsilon_{i, t}
$$

where Restate_Material $i_{, t}$ refers to whether the financial statement of firm $i$ is subject to a material restatement during year $t$. A material restatement is defined as a restatement with an above-median magnitude of cumulative change in net income scaled by total assets (Palmrose et al. 2004). The control variables and fixed effects are the same as in regression (1). A positive $\beta_{0}$ would suggest a higher likelihood of receiving a material restatement for PE-backed firms.

I supplement the material restatement measure with a persistence measure of the restatement (Palmrose et al. 2004). I run the following OLS regression conditional on the portfolio firm getting a restatement:

$$
\text { Restate_Period }_{i, t}=\alpha+\beta_{0} * P E_{i, t}+\sum_{j} \gamma_{j} * \text { Control }_{i, t}+\varepsilon_{i, t}
$$

where Restate_Period $d_{i, t}$ refers to the natural logarithm of the number of days between the restatement start date and end date for the restatement received by firm $i$ in year $t$. The control variables and fixed effects are the same as in regression (1). A positive $\beta_{0}$ would indicate a longer restatement duration for PE-backed firms.

To further examine the misreporting intention, I run the following logistic regression:

$$
A A E R_{i, t}=\alpha+\beta_{0} * P E_{i, t}+\sum_{j} \gamma_{j} * \text { Control }_{i, t}+\varepsilon_{i, t}
$$

where $A A E R_{i, t}$ refers to whether firm $i$ is subject to an SEC AAER during year $t$. The control variables and fixed effects are the same as in regression (1). A positive $\beta_{0}$ would indicate a heightened likelihood of receiving SEC enforcement for PE-backed firms.

\subsection{Sample selection}

I collect IPO data from SDC Platinum Global New Issues. The categorization of PE sponsorship and non-PE sponsorship is from the VentureXpert database of Thomson One, Jay 
Ritter's IPO categorization, ${ }^{20}$ and hand-collected data from S-1 filings on SEC EDGAR website. There are 3,301 IPOs with an offering date between January 1, 1998 and December 31, 2015, ${ }^{21}$ excluding ADRs, closed-end funds, REITs, special purpose acquisition companies, and those with an offering price less than $\$ 5$ per share. I require the sample to have common shares traded on U.S. exchanges, which leaves 2,896 IPOs. Then I require the availability of CIK, which allows me to extract company filings from SEC EDGAR and reduces the sample to 2,890 IPOs. I remove 1,414 IPOs backed by VC firms. ${ }^{22}$ For the remaining 589 PE-backed IPOs and 887 nonPE-backed IPOs, I obtain observations until five years after IPO, which is a reasonable timeframe for PE firms to realize the profits and exit the firm and is consistent with Katz (2009). ${ }^{23}$ After requiring necessary control variables and requiring PE firms continue to hold controlling power in the post-IPO period, I have 3,146 firm-year observations, in which 1,007 firm-years are PE-backed, and 2,139 firm-years are non-PE-backed.

I merge the sample to the Audit Analytics restatement database. There are 521 firm-years in my sample subject to a restatement. AAER data is available on the SEC AAER website. ${ }^{24}$ There are 39 firm-years in my sample subject to an AAER. I obtain firm characteristics from Compustat, institutional ownership from Thomson Reuters Institutional Holdings (13F), analyst coverage from I/B/E/S, auditor information from Audit Analytics, and PE firm characteristics from Thomson One.

\footnotetext{
${ }^{20}$ I thank Jay Ritter for sharing IPO classification data.

${ }^{21}$ I start from 1998 to ensure more accurate coverage from SEC AAER database and Audit Analytics database. I stop at 2015 to allow for observation of post-IPO outcomes.

${ }^{22} \mathrm{VC}$ firms tend to invest in firms at early stages and only take minority stakes in portfolio firms. The incentives of VC firms are systematically different from PE firms.

${ }^{23}$ Since the typical PE fund life is ten years and the average buyout holding is about five years in the past decade (Preqin 2018), five years after IPO is a reasonable expectation for PE firms to exit the portfolio firm.

${ }^{24}$ The data is available at https://www.sec.gov/divisions/enforce/friactions.shtml. I thank Wei Zhu, Jeremy McClane, and Kai Du for sharing AAER data.
} 


\section{Empirical Results}

\subsection{Descriptive statistics}

Table 1, Panel A reports the summary statistics for PE sponsorship and the main dependent variables in my sample. 32\% of the firm-years in the sample are backed by PE firms. The average probability of reporting a restatement is $16.6 \%$. The average probability of having a material restatement is $7.3 \%{ }^{25}$ The likelihood of receiving an AAER is $1.2 \%$. Table 1, Panel B presents the distribution of the sample by IPO year. 37\% of the PE-backed firm-years are between 2004 and 2007, which is an IPO booming period for the PE industry. 47\% of the nonPE-backed firm-years are between 1998 and 2000, which is the dot com bubble period. Table 1, Panel C presents the distribution of the sample by industry. Different industries are well represented. PE-backed firms tend to concentrate on the manufacturing industry (SIC codes 2039). Non-PE-backed firms tend to concentrate on the services industry (SIC codes 70-89). Table 1, Panel D illustrates the average number of issues encountered for each restated firm-year by the restatement reason. PE-backed firms have more accounting application failures and financial fraud, irregularities, and misrepresentations than non-PE-backed firms. Table 1, Panel E shows the portion of the restated firm-years out of total restated firm-years by the restatement category for PE-backed and non-PE-backed firms, respectively. Only the categories with significant differences are reported. PE-backed firms are more likely to have restatements related to depreciation and amortization, PPE and intangibles, liabilities, capital adequacy, tax expense, lease, and expenditure capitalization issues than non-PE-backed firms.

\section{[Insert Table 1 here]}

\footnotetext{
${ }^{25}$ There are restated firm-years without a cumulative change in net income value in Audit Analytics because some firms do not make a clear disclosure. Classifying these restated firm-years into material or immaterial restatement does not affect the results.
} 
Table 2 reports the correlation between the main dependent variables and independent variables. The correlation between PE sponsorship and the occurrence of a restatement or a material restatement is positive and significant. The correlation between PE sponsorship and receiving an AAER is positive but statistically insignificant.

[Insert Table 2 here]

\subsection{Entropy balancing}

It is likely that PE firms select portfolio firms based on certain firm characteristics, and these features are related to financial misreporting. To mitigate endogeneity concerns, I adopt entropy balancing (Heinmueller 2012) that balances the mean, variance, and skewness of covariates for PE-backed and non-PE-backed firm-years.

Table 3 presents the summary statistics for the sample before and after entropy balancing. Before entropy balancing, PE-backed firms are larger and older than non-PE-backed firms. Consistent with PE firms using debt to finance portfolio firms, PE-backed firms have higher leverage than non-PE-backed firms. PE-backed firms are higher in profitability and capital expenditure and lower in market-to-book ratio, sales growth, loss occurrence, and cash holdings. PE-backed firms have higher analyst coverage and institutional ownership than non-PE-backed firms, suggesting that PE-backed firms may receive greater public attention and monitoring. PEbacked firms tend to choose a Big $\mathrm{N}$ auditor than non-PE-backed firms. After entropy balancing, the differences in the mean, variance, and skewness between PE-backed firms and non-PEbacked firms are insignificant, suggesting that the sample achieves covariate balance.

[Insert Table 3 here]

\subsection{Financial misreporting}


To test H1, I run regression (1) with the entropy-balanced sample. The result of estimating the likelihood of getting a restatement for PE-backed firm-years vs. non-PE-backed firm-years is presented in Table 4, Panel A column (1). A positive and significant coefficient of $P E(0.492, t=2.15)$ rejects the null form of H1. Compared with non-PE-backed firms, PE-backed firms are significantly more likely to receive a restatement during the five-year post-IPO period. PE sponsorship increases the likelihood of restatement by $5.70 \%$.

Next, I run regression (2a) and report the result of estimating the likelihood of getting a material restatement for PE-backed firms vs. non-PE-backed firms in Table 4, Panel A column (2). A positive and significant coefficient of $P E(0.971, t=3.00)$ rejects H1. PE-backed firms are significantly more likely to incur a material restatement during the five-year post-IPO period. PE sponsorship increases the likelihood of material restatement by $5.85 \%$.

The result of estimating the restatement duration for PE-backed and non-PE-backed firmyears from regression (2b) is in Table 4, Panel A column (3). A positive and significant coefficient of $P E(0.256, t=2.58)$ suggests that PE-backed firms are likely to incur a restatement with a longer duration. Ceteris paribus, PE sponsorship increases the restated period by $25.6 \%$. The occurrence of a restatement is the joint outcome of a misstatement occurring and the auditor failing to detect or report the misstatement (DeAngelo 1981). The fact that PE-backed firms have a longer restated period further rules out the alternative explanation that auditors' heightened attention to PE-backed firms drives the different restatement likelihood between PE-backed and non-PE-backed firms. ${ }^{26}$

\footnotetext{
${ }^{26}$ On average, the number of days between the start date of the restated period and the restatement announcement date for PE-backed and non-PE-backed firms is 1,336 days and 1,324 days, respectively (not statistically different). The number of days between the end date of the restated period and the restatement announcement date for PEbacked and non-PE-backed firms is 204 days and 226 days, respectively. The difference has marginal significance. The statistics on restatement reporting lag go against the heightened auditor attention explanation.
} 
Table 4, Panel A column (4) shows the result of estimating the likelihood of getting an AAER for PE-backed and non-PE-backed firm-years using regression (3). A positive and significant coefficient of $P E(2.241, t=2.27)$ rejects H1. PE-backed firms are significantly more likely to receive an AAER during the five-year post-IPO period. PE sponsorship increases the likelihood of receiving an AAER by $5.92 \%$.

\section{[Insert Table 4 here]}

As PE firms have the ultimate goal of exiting from portfolio firms, it would be in their best interest to conduct manipulations before they exit the firm. Besides the PE-backed firmyears in the current sample (Before_Exit), I add PE-backed firm-years when PE firms own less than $20 \%$ of the portfolio firms or no longer serve as the largest shareholder (After_Exit). In other words, the additional sample contains PE-backed firm-years in which PE firms lose controlling power. ${ }^{27}$ I run the same regressions replacing PE dummy with Before_Exit and After_Exit, indicating the status of whether PE firms exit from the portfolio firms. The results are presented in Table 4, Panel B.

As shown in Table 4, Panel B columns (1) to (4), the coefficient of Before_Exit is significant and positive across all regressions, meaning that PE-backed firms are more likely to have a restatement, a material restatement, a restatement with long restated period, or an AAER before PE firms' exit compared with non-PE-backed firms. The results confirm that when PE firms are still present after IPO, portfolio firms are more likely to engage in manipulations that facilitate PE firms to extract profits.

\subsection{Additional analysis}

\footnotetext{
${ }^{27}$ I choose $20 \%$ as the threshold as over $20 \%$ of ownership interest is often viewed as having significant influence.
} 
In this section, I analyze the reasons why PE-backed firms have more financial misreporting, represented by a higher likelihood of incurring restatements, material restatements, and AAERs. I propose that PE firms' impact on portfolio firms is the result of the following two mechanisms: the pursuit of profits and captured board and executives.

\subsubsection{Pursuit of profits}

I conjecture that PE-backed firms are more likely to misreport when PE firms possess wealth expropriation incentives. To speak to the motivation of PE firms, I conduct crosssectional analysis that divides the sample into firm-years in which PE firms sell a large portion of ownership, i.e., $5 \%,{ }^{28}$ and firm-years without a large sell. I run the same regressions replacing PE with two dummy variables, Large_Sell and Non_Large_Sell, indicating whether PE firms dispose of a large portion of the ownership. The results are presented in Table 5.

Table 5 column (1) shows that the likelihood of getting a restatement is higher for PEbacked firms in both large-sell years and non-large-sell years. The coefficient is slightly higher for large-sell years, albeit the difference between the coefficients of Large_Sell and Non_Large_Sell is not statistically significant. Table 5 column (2) shows that during large-sell years, PE-backed firms are significantly more likely to get a material restatement. Table 5 column (3) shows that the restatements by PE-backed firms have a longer restated period in both large-sell years and non-large-sell years. Table 5 column (4) shows that during both large-sell and non-large-sell years, PE-backed firms are significantly more likely to get AAERs. ${ }^{29}$ The results indicate that the financial misreporting of PE-backed firms can be driven by PE firms' incentives to sell shares.

\footnotetext{
${ }^{28}$ When a party acquires $5 \%$ of the shares, it must disclose its beneficial ownership by filing Schedule 13D with the SEC. It is reasonable to assume that selling 5\% of the shares qualifies as a large sell for an insider.

${ }^{29}$ I find similar results when using an alternative definition of a large-sell year that indicates whether PE firms sell more than $5 \%$ relative to the initial holding after IPO.
} 


\section{[Insert Table 5 here]}

Moreover, untabulated results suggest that PE-backed firms are more likely to receive an AAER during years when PE funds are younger (i.e., existing for no more than five years after the vintage year). As PE firm contracts encourage early exit to boost internal rate of return and carried interest, the results confirm that when the incentives to extract profit are larger, portfolio firms are more likely to misreport. Overall, the results are consistent with PE firms' opportunistic behaviors to extract profit at the cost of existing shareholders after the IPO.

\subsubsection{Captured board and executives}

To examine whether PE firms impact portfolio firms' financial misreporting through captured board and executives channel, I test whether the main results are affected by the retaining ownership by PE firms, which reflects PE firms' power to influence the board and executives of portfolio firms. I run the same regressions replacing $P E$ with a continuous measure of PE ownership, PE_Own. The results are presented in Table 6, Panel A. Column (1) of Panel A shows that the likelihood of getting a restatement is not associated with PE ownership. However, columns (2) and (3) of Panel A show that PE-backed firms with higher PE ownership are more likely to have a material restatement or a longer restated period than non-PE-backed firms. One percentage increase in shares held by PE firms increases the likelihood of getting a material restatement by $0.08 \%$ or the length of the restated period by $0.5 \%$. Column (4) of Panel A shows that PE-backed firms with higher PE ownership are more likely to receive an AAER.

Moreover, larger PE firms may possess stronger controlling power in the portfolio firms. I examine whether the PE firm size is related to financial misreporting. I run the same regressions replacing $P E$ with two dummy variables: $P E \_$Large, representing large PE firms with above-median assets under management within the sample, and $P E \_S m a l l$, representing 
small PE firms with below-median assets under management. The results are reported in Panel B of Table 6. Columns (1) and (2) of Panel B show that both large and small PE firms have a significant impact on the likelihood of receiving a restatement or a material restatement by portfolio firms. Column (3) of Panel B suggests that restatement duration is longer for firms backed by large PE firms. Column (4) of Panel B shows that firms backed by both large and small PE firms are more likely to receive an AAER.

\section{[Insert Table 6 here]}

Furthermore, I examine whether the controlling power of PE firms is manifested in board characteristics, proxy voting behaviors, and class action claims. I link my sample to BoardEx to get board size (BodSize), the number of independent board members (Independence), whether the majority of the board is independent (Independent), and whether the CEO serves as the chairman of the board (CeoChair). Due to the limited coverage of BoardEx, my sample reduces to 1,997 firm-years after merging. Table 6, Panel $\mathrm{C}$ shows that PE-backed firms are less likely to have a CEO serving as the chairman of the board than non-PE-backed firms, consistent with the notion that PE firms control the board with their personnel. ${ }^{30}$

I merge my sample with Institutional Shareholder Services (ISS) Voting Analytics to study voting patterns. Because ISS Voting Analytics only covers Russell 3000 between 2003 and 2012 and other US companies after 2013, I end up with 1,474 firm-years with vote records. I examine whether the management dissents from the ISS recommendations (Disagree) and when there is a discrepancy in the opinion of the management and the ISS, whether the voting results

\footnotetext{
${ }^{30}$ Untabulated results show that PE-backed firms with a CEO chairing the board are more likely to receive material restatements than other PE-backed firms and non-PE-backed firms, suggesting that once a CEO is under the control of the PE firm, he or she is "captured", and the likelihood of engaging in misreporting increases.
} 
favor the management (MgmtWin). ${ }^{31}$ Table 6, Panel D shows that PE-backed firms are more likely to have an annual shareholder meeting involving disagreeing opinions between the management and the ISS, and the management in PE-backed firms is more likely to win the vote when there is a disagreeing opinion. Table 6 , Panel E shows that $84 \%$ of the dissenting proposals in the PE-backed firms are related to the director election. The descriptive statistics suggest that PE firms may use their controlling power to exploit minority shareholders and that PE firms have dominant control over the process of board election and voting, which weakens board monitoring but favors manipulations in the interest of PE firms.

I further merge my sample with Audit Analytics Litigation dataset to obtain legal cases faced by portfolio firms. Untabulated results suggest that conditional on receiving a class action, PE-backed firms are more likely to receive a claim on director and officer liability than non-PEbacked firms.

Overall, the results are consistent with the channel that the board of directors and executives in the portfolio firms are captured by PE firms, resulting in financial misreporting.

\subsection{Robustness checks}

In this section, I rule out several alternative explanations for the main results. The occurrence of an AAER is the joint outcome of firm misreporting and the SEC's attention, and differential regulatory attention may drive the AAER results. Further, the results might be attributable to the selection effect of PE firms rather than PE firms' impact after the buyout. In

\footnotetext{
${ }^{31}$ I also compare PE-backed firms with non-PE-backed firms regarding whether the voting passes or fails within a 5\% margin of the voting requirement (CloseVote) (Iliev and Lowry 2015), and the percentage of the proposals sponsored by the management (SponsorMgmt) and the shareholders (SponsorSh). Table 6, Panel D shows that PEbacked firms are less likely to have a vote close to the voting requirement, consistent with the perception that PE firms have major controls over the votes. Table 6, Panel D also shows that the proposals are more (less) likely to be sponsored by the management (shareholders) for PE-backed firms than non-PE-backed firms, consistent with the belief that minority shareholders in PE-backed firms have fewer chances to express their opinions due to the dominant control of PE firms.
} 
addition, the results might be sensitive to the proxies adopted. I discuss each of the alternative explanations in the following subsections and reconcile the results with Katz (2009).

\subsubsection{Regulatory attention}

PE-backed firms may attract more regulatory attention, which leads to a higher likelihood of AAERs. I examine the probability of receiving a subsequent securities class action or an SEC investigation conditional on receiving a restatement. If the results are driven by regulatory attention, I should be able to find a restated PE-backed firm-year more likely to be sued than a restated non-PE-backed firm-year. I run the same regression as regression (1) using only the restated firm-years, replacing the dependent variable with Restate_SCA and Restate_SEC, indicating whether the restatement gets a subsequent securities class action or an SEC investigation. The results are shown in Table 7 . I do not find a difference in getting subsequent lawsuits for PE-backed and non-PE-backed firms upon receiving a restatement. ${ }^{32,33}$

\section{[Insert Table 7 here]}

\subsubsection{Selection issues - Heckman model}

Although entropy balancing increases the confidence that the results are not driven by PE firms' selection effect, I follow the Heckman (1979) procedure to mitigate the concern that the negative impact of PE firms is driven by PE firms selecting certain firms with characteristics correlated with financial misreporting. In the first stage, I estimate a probit model with $P E$ as the dependent variable, and Size, MTB, Lev, ROA, SaleGr, Capex, Loss, Cash, 2-digit SIC industry code dummy, and IPO year dummy as predictors. I compute Inverse Mills Ratio (IMR) from the

\footnotetext{
${ }^{32}$ Untabulated results show that conditional on receiving a material restatement, PE-backed firms have no difference in the likelihood of getting a subsequent securities class action or a subsequent SEC investigation.

${ }^{33}$ I merge my sample with Audit Analytics Comment Letter dataset to obtain comment letters received by portfolio firms after 2004. Untabulated results suggest that conditional on receiving a restatement or a material restatement, the likelihood of receiving a comment letter by PE-backed firms is not different from non-PE-backed firms.
} 
estimates of the probit model and add it to the second stage as an additional control variable.

Table 8, Panel A suggests that the main results are robust to the selection effect.

[Insert Table 8 here]

\subsubsection{Selection issues - Instrumental variable}

To mitigate the concern that unobservable characteristics between PE-backed and nonPE-backed firms may drive the financial misreporting differences, I further adopt an instrumental variable to cope with the endogeneity problem. I use the ratio of the number of PE-backed IPO firms to the number of all IPO firms in the same industry and IPO year of the portfolio firm $\left(P E \_\right.$Ratio $)$as an instrument.

A valid instrument satisfies two criteria: (1) instrument relevance; (2) instrument exogeneity (Wooldridge 2016). The first stage result in Table 8, Panel B column (1) shows that $P E_{-}$Ratio fulfills the instrument relevance. The coefficient of $P E_{-}$Ratio is 0.854 and highly significant, suggesting that an IPO is more likely to have PE ownership when the portion of IPOs backed by PE firms in the same industry and IPO year is higher. PE_ Ratio satisfies instrument exogeneity if the ratio of PE-backed IPOs in the same industry and IPO year affects the financial misreporting of the portfolio firm only through PE ownership. The ratio of PE-backed firms in the same industry and IPO year is not a choice by portfolio firms and is unlikely to be a consideration in the investment opportunity screening process of PE firms.

The second stage results are presented in Table 8, Panel B columns (2) to (5). The instrumented PE (PE_IV) continues to be positively associated with the financial misreporting of portfolio firms across all regressions. The instrumental variable approach provides consistent evidence with the main results.

\subsubsection{Reconciliation with Katz (2009)}


The findings of financial misreporting in terms of restatement and AAER occurrence are seemingly contradictory to the higher financial reporting quality measured by discretionary accruals (Katz 2009). My study differs from Katz (2009) in two aspects. First, I use external indicators of low-quality accounting (i.e., restatements and SEC enforcement releases) rather than abnormal accruals models. Research suggests that abnormal accruals suffer from model misspecification and reflect investment or temporary fluctuations in working capital (Fairfield et al. 2003; Dechow et al. 2010; Allen et al. 2013). ${ }^{34}$ Restatements and SEC enforcement releases, on the other hand, have less measurement bias and can more accurately capture deviations from U.S. GAAP due to managerial manipulation. Second, I compile a more comprehensive sample that extends to recent years. This extension is important because the past decade has witnessed substantial growth in the PE market and a changing landscape of financial reporting regulations.

I use my sample to replicate the findings of Katz (2009) using discretionary accruals from modified Jones model (D_WACC_MDD) (Dechow et al. 1995), modified Dechow-Dichev model $\left(D \_W A C C \_B S\right)$ (Ball and Shivakumar 2006), and performance-matched model (D_WACC_PM) (Kothari et al. 2005). The results are shown in Table 9 columns (1) to (3). The results of Katz (2009) still hold in my sample period.

Several possible explanations exist for the difference between my results and Katz (2009). First, PE firms might behave differently in different regulatory regimes (e.g., pre- and post-SOX). Second, discretionary accruals and restatements or AAERs capture different aspects of financial reporting quality. Discretionary accruals capture within GAAP variations, whereas

\footnotetext{
${ }^{34}$ Accruals models are subject to misclassification errors, including classifying accruals as abnormal when they represent fundamental performance (Type I error) and classifying accruals as normal when they are not (Type II error). Discretionary accruals are highly correlated with total accruals and earnings performance, suggesting a high Type I error rate (Dechow et al. 1995; Dechow et al. 2003). Discretionary accruals are less powerful than total accruals in predicting AAERs, indicating a high Type II error rate (Dechow et al. 2011). In contrast, restatements and AAERs do not rely on model specifications, and have lower Type I error rates.
} 
restatements and AAERs are external indicators of financial reporting quality. Further, discretionary accruals might reflect firm growth rather than misreporting.

For the first explanation, I test whether the results are sensitive to the sample period. Due to the changes in audit procedures after SOX, I run the same regressions using only firm-years in the pre- or post-SOX period. Untabulated results suggest that all the main results hold in the post-SOX period. For the pre-SOX period, restatement duration results continue to hold. Longer restated period for PE-backed firms in both pre- and post-SOX period mitigates the concern that different regulation regimes drive the difference with Katz (2009).

For the second explanation, I check whether firm growth might explain the discretionary accrual results. I run the same regression with dependent variables as the change in the number of employees (Ch_Emp) (Dechow et al. 2011) and growth in long-term net operating assets (GrLTNOA) (Fairfield et al. 2003). I cannot completely rule out growth explanation for the results in Katz (2009) as Table 9 columns (4) and (5) show that PE sponsorship is significantly negatively associated with Ch_Emp and GrLTNOA.

\section{[Insert Table 9 here]}

Based on the above discussions, it is less likely that different behaviors or incentives of PE firms across regulatory periods drive the contradictories. It is likely that restatements and AAERs capture more egregious misreporting whereas discretionary accruals reflect withinGAAP variations. It is also likely that discretionary accruals reflect firm growth rather than financial misreporting.

\subsubsection{Materiality measures}

I test whether the results on material restatement are sensitive to using the median as a cutoff for materiality. I redefine a material restatement as a dummy variable which equals 1 if the 
firm has an above-75-percentile magnitude of cumulative misstatement of net income scaled by total assets. The results are robust to this alternative definition of a material restatement. Moreover, I redefine a material restatement as a dummy variable which equals 1 if the firm files an 8-K item 4.02 after the restatement ("big r"). The results are robust to using "big r" as an alternative definition. I also define a material restatement as a dummy variable which equals 1 if a restatement involves revenue recognition errors, or revenue recognition errors and serious core expense errors (Zakolyukina 2018). ${ }^{35}$ The results are robust. I further remove restatements due to clerical errors, and the results still hold.

I test whether the results on the length of restatement are affected if I use the number of quarters affected by the restatement rather than the logarithm number of days restated. The results are robust to the alternative definition of restatement duration.

\section{Conclusion}

Using a sample of firms that went public between 1998 and 2015, I find that PE-backed firms are more likely to receive material restatements and AAERs in the five-year period after IPO. The results are stronger before PE firms finally exit from portfolio firms. I show that PEbacked firms incur more financial misreporting because of PE firms' pursuit of profits and their control over the board and executives. Consistent with the "pursuit of profits" channel, PEbacked firms are more likely to engage in egregious misreporting during periods when PE firms dispose of their ownership to a greater extent. Consistent with the "captured board and

\footnotetext{
${ }^{35}$ Serious core expense errors include inventory, vendor and/or cost of sales issues (20); liabilities, accounts payable, reserves, and accrual estimate failures (12); and capitalization of expenditures issues (23). Audit Analytics restatement category keys are in parentheses.
} 
executives" channel, the likelihood of misreporting is higher when PE firms' power over the board is more dominant.

Overall, this paper offers new understandings of how PE firms affect portfolio firms. Rather than providing extraordinary governance, PE firms may harm portfolio firms' financial reporting quality. Given the importance of the PE industry as well as the recent regulatory concerns, I provide timely implications for investors, auditors, and regulators. As this paper only examines the IPO sample of portfolio firms, future research can explore whether the inferences can be generalized to other settings such as mergers and acquisitions. Future studies can further analyze how PE ownership affects auditor selection and audit quality. 


\section{References}

Abry Partners V, LP v. F \& W Acquis. LLC, 891 A.2d 1032 (Del. Ch. 2006).

Acharya, V. V., Gottschalg, O. F., Hahn, M., \& Kehoe, C. (2013). Corporate governance and value creation: Evidence from private equity. The Review of Financial Studies, 26(2), 368-402.

Allen, E. J., Larson, C. R., \& Sloan, R. G. (2013). Accrual reversals, earnings and stock returns. Journal of Accounting and Economics, 56(1), 113-129.

Badertscher, B. A., Katz, S. P., \& Rego, S. O. (2013). The separation of ownership and control and corporate tax avoidance. Journal of Accounting and Economics, 56(2-3), 228-250.

Beneish, M. D. (1999). Incentives and penalties related to earnings overstatements that violate GAAP. The Accounting Review, 74(4), 425-457.

Bernstein, S., \& Sheen, A. (2016). The operational consequences of private equity buyouts: Evidence from the restaurant industry. The Review of Financial Studies, 29(9), 2387-2418.

Bhagat, S., Shleifer, A., Vishny, R. W., Jarrel, G., \& Summers, L. (1990). Hostile takeovers in the 1980s: The return to corporate specialization. Brookings Papers on Economic Activity. Microeconomics, 1990, $1-84$.

Bloom, N., Sadun, R., \& Van Reenen, J. (2015). Do private equity owned firms have better management practices?. American Economic Review, 105(5), 442-46.

Brown, G. W., Harris, R. S., Jenkinson, T., Kaplan, S. N., \& Robinson, D. T. (2015). What do different commercial data sets tell us about private equity performance?. Working Paper, available at SSRN: https://ssrn.com/abstract=2706556.

Burns, N., Kedia, S., \& Lipson, M. (2010). Institutional ownership and monitoring: Evidence from financial misreporting. Journal of Corporate Finance, 16(4), 443-455.

Carhart, M. M. (1997). On persistence in mutual fund performance. The Journal of Finance, 52(1), 57-82.

Cao, J. X. (2011). IPO timing, buyout sponsors' exit strategies, and firm performance of RLBOs. Journal of Financial and Quantitative Analysis, 46(4), 1001-1024.

Cao, J., \& Lerner, J. (2009). The performance of reverse leveraged buyouts. Journal of Financial Economics, 91(2), 139-157.

Cheng, C. A., Huang, H. H., \& Li, Y. (2015). Hedge fund intervention and accounting conservatism. Contemporary Accounting Research, 32(1), 392-421.

Chou, D. W., Gombola, M., \& Liu, F. Y. (2006). Earnings management and stock performance of reverse leveraged buyouts. Journal of Financial and Quantitative Analysis, 41(2), 407-438.

Cohn, J. B., Mills, L. F., \& Towery, E. M. (2014). The evolution of capital structure and operating performance after leveraged buyouts: Evidence from US corporate tax returns. Journal of Financial Economics, 111(2), 469-494.

Cotter, J. F., \& Peck, S. W. (2001). The structure of debt and active equity investors: The case of the buyout specialist. Journal of Financial Economics, 59(1), 101-147.

Dahl v. Bain Capital Partners, LLC, 983 F. Supp. 2d 185 (D. Mass. 2013).

Davis, S. J., Haltiwanger, J., Handley, K., Jarmin, R., Lerner, J., \& Miranda, J. (2014). Private equity, jobs, and productivity. American Economic Review, 104(12), 3956-3990.

DeAngelo, L. E. (1981). Auditor independence, 'low balling', and disclosure regulation. Journal of Accounting and Economics, 3(2), 113-127.

Dechow, P. M., Ge, W., Larson, C. R., \& Sloan, R. G. (2011). Predicting material accounting misstatements. Contemporary Accounting Research, 28(1), 17-82.

Dechow, P., Ge, W., \& Schrand, C. (2010). Understanding earnings quality: A review of the proxies, their determinants and their consequences. Journal of Accounting and Economics, 50(2-3), 344-401.

Dechow, P. M., Richardson, S. A., \& Tuna, I. (2003). Why are earnings kinky? An examination of the earnings management explanation. Review of Accounting Studies, 8(2-3), 355-384.

Dechow, P. M., Sloan, R. G., \& Sweeney, A. P. (1995). Detecting earnings management. The Accounting Review, 70(2), 193-225.

Dechow, P. M., Sloan, R. G., \& Sweeney, A. P. (1996). Causes and consequences of earnings manipulation: An analysis of firms subject to enforcement actions by the SEC. Contemporary Accounting Research, 13(1), 1-36. 
DeFond, M. L., \& Jiambalvo, J. (1994). Debt covenant violation and manipulation of accruals. Journal of Accounting and Economics, 17(1-2), 145-176.

Degeorge, F., \& Zeckhauser, R. (1993). The reverse LBO decision and firm performance: Theory and evidence. The Journal of Finance, 48(4), 1323-1348.

Demiroglu, C., \& James, C. M. (2010). The role of private equity group reputation in LBO financing. Journal of Financial Economics, 96(2), 306-330.

Dou, Y., Hope, O. K., Thomas, W. B., \& Zou, Y. (2016). Individual large shareholders, earnings management, and capital-market consequences. Journal of Business Finance \& Accounting, 43(7-8), 872-902.

Efendi, J., Srivastava, A., \& Swanson, E. P. (2007). Why do corporate managers misstate financial statements? The role of option compensation and other factors. Journal of Financial Economics, 85(3), 667-708.

Ernst \& Young LLP. (2018). Understanding PE's Impact on the Economy. Available at https://www.ey.com/Publication/vwLUAssets/ey-understanding-pes-impact-on-the-economy/\$File/eyunderstanding-pes-impact-on-the-economy.pdf.

Ertimur, Y., Sletten, E., \& Sunder, J. (2014). Large shareholders and disclosure strategies: Evidence from IPO lockup expirations. Journal of Accounting and Economics, 58(1), 79-95.

Fairfield, P. M., Whisenant, J. S., \& Yohn, T. L. (2003). Accrued earnings and growth: Implications for future profitability and market mispricing. The Accounting Review, 78(1), 353-371.

Feroz, E. H., Park, K., \& Pastena, V. S. (1991). The financial and market effects of the SEC's accounting and auditing enforcement releases. Journal of Accounting Research, 29, 107-142.

Folus, D., \& Boutron, E. (2015). Exit Strategies in Private Equity. Private Equity: Opportunities and Risks, 215-238. Oxford University Press.

Gleason, C. A., Jenkins, N. T., \& Johnson, W. B. (2008). The contagion effects of accounting restatements. The Accounting Review, 83(1), 83-110.

Gompers, P. A. (1996). Grandstanding in the venture capital industry. Journal of Financial Economics, 42(1), 133-156.

Guo, S., Hotchkiss, E. S., \& Song, W. (2011). Do buyouts (still) create value?. The Journal of Finance, 66(2), 479-517.

Heckman, J. J. (1979). Sample selection bias as a specification error. Econometrica: Journal of the econometric society, 153-161.

Hainmueller, J. (2012). Entropy balancing for causal effects: A multivariate reweighting method to produce balanced samples in observational studies. Political Analysis, 20(1), 25-46.

Hennes, K. M., Leone, A. J., \& Miller, B. P. (2008). The importance of distinguishing errors from irregularities in restatement research: The case of restatements and CEO/CFO turnover. The Accounting Review, 83(6), 1487-1519.

Holthausen, R. W., \& Larcker, D. F. (1996). The financial performance of reverse leveraged buyouts. Journal of Financial Economics, 42(3), 293-332.

Huang, R., Ritter, J. R., \& Zhang, D. (2016). Private equity firms' reputational concerns and the costs of debt financing. Journal of Financial and Quantitative Analysis, 51(1), 29-54.

In Re Topps Co. Shareholders Litigation, 926 A.2d 58 (Del. Ch. 2007).

Iliev, P., \& Lowry, M. (2015). Are mutual funds active voters?. The Review of Financial Studies, 28(2), 446485.

Ivashina, V., \& Kovner, A. (2011). The private equity advantage: Leveraged buyout firms and relationship banking. The Review of Financial Studies, 24(7), 2462-2498.

Jackson Jr, R. J. (2013). Private equity and executive compensation. UCLA Law Review, 60, 638.

Jensen, M. C. (1989). Eclipse of the public corporation. Harvard Business Review.

Kaplan, S. N., \& Strömberg, P. (2009). Leveraged buyouts and private equity. Journal of Economic Perspectives, 23(1), 121-146.

Karpoff, J. M., Lee, D. S., \& Martin, G. S. (2008). The consequences to managers for financial misrepresentation. Journal of Financial Economics, 88(2), 193-215. 
Katz, S. P. (2009). Earnings quality and ownership structure: The role of private equity sponsors. The Accounting Review, 84(3), 623-658.

Kosman, J. (2009). The buyout of America: How private equity will cause the next great credit crisis. Penguin, New York.

Larcker, D. F., Richardson, S. A., \& Tuna, I. (2007). Corporate governance, accounting outcomes, and organizational performance. The Accounting Review, 82(4), 963-1008.

Lee, P. M., \& Wahal, S. (2004). Grandstanding, certification and the underpricing of venture capital backed IPOs. Journal of Financial Economics, 73(2), 375-407.

Leslie, P., \& Oyer, P. (2009). Managerial incentives and value creation: Evidence from private equity. Working Paper, available at SSRN: https://ssrn.com/abstract=1341889.

Levis, M. (2011). The performance of private equity-backed IPOs. Financial Management, 40(1), 253-277. Magnuson, W. (2017). The Public Cost of Private Equity. Minnesota Law Review, 102, 1847-1910.

Masulis, R. W., \& Thomas, R. S. (2009). Does Private Equity Create Wealth? The Effects of Private Equity and Derivatives on Corporate Governance. The University of Chicago Law Review, 76, 219-260.

Megginson, W. L., \& Weiss, K. A. (1991). Venture Capitalist Certification in Initial Public Offerings. The Journal of Finance, 46(3), 879-903.

Metrick, A., \& Yasuda, A. (2011). Venture capital and other private equity: a survey. European Financial Management, 17(4), 619-654.

Mian, S., \& Rosenfeld, J. (1993). Takeover activity and the long-run performance of reverse leveraged buyouts. Financial Management, 22, 46-57.

Muscarella, C. J., \& Vetsuypens, M. R. (1990). Efficiency and organizational structure: A study of reverse LBOs. The Journal of Finance, 45(5), 1389-1413.

Phalippou, L. (2009). Beware of venturing into private equity. Journal of Economic Perspectives, 23(1), $147-166$.

Rappaport, A. (1990). The staying power of the public corporation. Harvard Business Review, 68(1), 96104.

Renneboog, L., \& Vansteenkiste, C. (2017). Leveraged buyouts: an overview of the literature. Working Paper, available at SSRN: https://ssrn.com/abstract=2896653.

Shleifer, A., \& Vishny, R. W. (1997). A survey of corporate governance. The Journal of Finance, 52(2), 737-783.

Palmrose, Z. V., Richardson, V. J., \& Scholz, S. (2004). Determinants of market reactions to restatement announcements. Journal of Accounting and Economics, 37(1), 59-89.

Palmrose, Z. V., \& Scholz, S. (2004). The circumstances and legal consequences of non-GAAP reporting: Evidence from restatements. Contemporary Accounting Research, 21(1), 139-180.

Preqin. (2018). 2018 Preqin Global Private Equity \& Venture Capital Report. Available at https://www.preqin.com/insights/global-alternatives-reports.

Preqin. (2019). Preqin Quarterly Update: Private Equity \& Venture Capital, Q3 2019. Available at https://www.preqin.com/insights/quarterly-updates/preqin-quarterly-update-private-equity-venturecapital-q3-2019/26495.

Preqin. (2020). 2020 Preqin Global Private Equity \& Venture Capital Report. Available at https://www.preqin.com/insights/global-alternatives-reports/2020-preqin-global-private-equity-venturecapital-report/26652.

Wooldridge, J. M. (2016). Introductory econometrics: a modern approach. Mason, OH: Thomson/SouthWestern.

Wruck, K. H. (1989). Equity ownership concentration and firm value: Evidence from private equity financings. Journal of Financial Economics, 23(1), 3-28.

Zakolyukina, A. A. (2018). How common are intentional GAAP violations? Estimates from a dynamic model. Journal of Accounting Research, 56(1), 5-44. 


\section{Appendix A: Variable Definitions}

\begin{tabular}{|c|c|}
\hline Variable & Definition \\
\hline$P E$ & $\begin{array}{l}\text { PE sponsorship is defined as a dummy variable which equals } 1 \text { if the portfolio firm } \\
\text { is backed by PE firms, and } 0 \text { otherwise }\end{array}$ \\
\hline Restatement & $\begin{array}{l}\text { Restatement is defined as a dummy variable which equals } 1 \text { if the firm has a restated } \\
\text { financial statement during year } t \text {, and } 0 \text { otherwise }\end{array}$ \\
\hline Restate_Material & $\begin{array}{l}\text { Material restatement is defined as a dummy variable which equals } 1 \text { if the firm has } \\
\text { an above-median magnitude of misstatement of net income scaled by total assets } \\
\text { during year } t \text {, and } 0 \text { otherwise (Palmrose et al. 2004) })^{36}\end{array}$ \\
\hline Restate_Period & $\begin{array}{l}\text { Restated period is defined as the natural logarithm of the number of days between } \\
\text { the restatement start date and end date }\end{array}$ \\
\hline$A A E R$ & $\begin{array}{l}\text { AAER is defined as a dummy variable which equals } 1 \text { if the firm is subject to an } \\
\text { SEC Accounting and Auditing Enforcement Release during year } t \text {, and } 0 \text { otherwise }\end{array}$ \\
\hline Restate_SCA & $\begin{array}{l}\text { Subsequent securities class action is defined as a dummy variable which equals } 1 \text { if } \\
\text { the firm is subject to a securities class action after the restatement, and } 0 \text { otherwise }\end{array}$ \\
\hline Restate_SEC & $\begin{array}{l}\text { SEC investigation in restatement is defined as a dummy variable which equals } 1 \text { if } \\
\text { the firm receives a restatement with SEC investigation during year } t \text {, and } 0 \text { otherwise }\end{array}$ \\
\hline Size & Firm size is defined as the natural logarithm of total assets in year $t$ \\
\hline MTB & $\begin{array}{l}\text { Market-to-book ratio is defined as total assets minus common shareholder equity } \\
\text { plus market capitalization (annual closing price times common shares outstanding), } \\
\text { scaled by total assets in year } t\end{array}$ \\
\hline Lev & $\begin{array}{l}\text { Leverage is defined as total liabilities (current debt plus long-term debt) divided by } \\
\text { common shareholders' equity in year } t\end{array}$ \\
\hline$R O A$ & $\begin{array}{l}\text { Profitability is defined as income before extraordinary items divided by total assets } \\
\text { in year } t\end{array}$ \\
\hline SaleGr & Sales growth is defined as the growth rate of sales from year $t-1$ to year $t$ \\
\hline Capex & Capital expenditure is defined as capital expenditures divided by total assets in year $t$ \\
\hline Loss & $\begin{array}{l}\text { Loss is defined as a dummy variable which equals } 1 \text { when the firm has negative net } \\
\text { income in year } t \text {, and } 0 \text { otherwise }\end{array}$ \\
\hline Cash & Cash is defined as cash and short-term investments divided by total assets in year $t$ \\
\hline Age & Firm age is defined as the number of years between the founding year and year $t$ \\
\hline IPO_Age & IPO age is defined as the number of years between the IPO offering year and year $t$ \\
\hline$B i g N$ & $\begin{array}{l}\text { Big } \mathrm{N} \text { auditor is defined as a dummy variable which equals } 1 \text { if the firm is audited } \\
\text { by a Big } \mathrm{N} \text { auditor during year } t \text {, and } 0 \text { otherwise }\end{array}$ \\
\hline NAnalyst & Analyst coverage is defined as the number of analysts who cover the firm in year $t$ \\
\hline InstOwn & $\begin{array}{l}\text { Institutional ownership is defined as the institutional investor holding percentage in } \\
\text { year } t\end{array}$ \\
\hline Ch_Rec & $\begin{array}{l}\text { Change in receivables is defined as the change in accounting receivables from year } t \text { - } \\
1 \text { to year } t \text { divided by total assets in year } t-1\end{array}$ \\
\hline Ch_Inv & $\begin{array}{l}\text { Change in inventory is defined as the change in inventory from year } t-1 \text { to year } t \\
\text { divided by total assets in year } t-1\end{array}$ \\
\hline Ch_Emp & $\begin{array}{l}\text { Change in employees is defined as the percentage change in the number of } \\
\text { employees from year } t-1 \text { to year } t\end{array}$ \\
\hline$C h \_R O A$ & $\begin{array}{l}\text { Change in return on assets is defined as the change in income before extraordinary } \\
\text { items from year } t-1 \text { to year } t \text {, divided by total assets in year } t-1\end{array}$ \\
\hline$C h \_C s$ & $\begin{array}{l}\text { Change in cash sales is defined as the percentage change in cash sales (sales minus } \\
\text { change in accounting receivables) from year } t-1 \text { to year } t\end{array}$ \\
\hline
\end{tabular}

\footnotetext{
${ }^{36}$ The measure adopted in Palmrose et al. (2004) is a continuous measure of the size of the restatement. I convert the measure into a dummy variable for a more straightforward interpretation of materiality.
} 


\begin{tabular}{|c|c|}
\hline Variable & Definition \\
\hline Before_Exit & $\begin{array}{l}\text { Before exit is defined as a dummy variable which equals } 1 \text { when PE firms still own } \\
\text { more than } 20 \% \text { of the shares or serve as the largest shareholder of the firm in year } t \text {, } \\
\text { and } 0 \text { otherwise }\end{array}$ \\
\hline After_Exit & After exit is defined as $P E$ minus Before_Exit \\
\hline Large_Sell & $\begin{array}{l}\text { Large-sell is defined as a dummy variable which equals } 1 \text { when PE firms sell more } \\
\text { than } 5 \% \text { of shares during year } t \text {, and } 0 \text { otherwise }\end{array}$ \\
\hline Non_Large_Sell & Non-large-sell is defined as $P E$ minus Large_Sell \\
\hline$P E \_O w n$ & PE ownership is the percentage of shares held by PE firms in year $t$ \\
\hline$P E \_$Large & $\begin{array}{l}\text { Large PE firm is defined as a dummy variable which equals } 1 \text { if the PE fund has } \\
\text { above-median fund size, and } 0 \text { otherwise }\end{array}$ \\
\hline PE_Small & $\begin{array}{l}\text { Small PE firm is defined as a dummy variable which equals } 1 \text { if the PE fund has } \\
\text { below-median fund size, and } 0 \text { otherwise }\end{array}$ \\
\hline BodSize & Board size is defined as the number of directors on the board in year $t$ \\
\hline Independence & $\begin{array}{l}\text { Board independence is defined as the number of independent board members in year } \\
t\end{array}$ \\
\hline Independent & $\begin{array}{l}\text { Independent board is defined as a dummy variable which equals } 1 \text { when the majority } \\
\text { of the board is independent in year } t \text {, and } 0 \text { otherwise }\end{array}$ \\
\hline CeoChair & $\begin{array}{l}\text { CEO duality is defined as a dummy variable which equals } 1 \text { if the CEO holds the } \\
\text { position of the chairman of the board in year } t \text {, and } 0 \text { otherwise }\end{array}$ \\
\hline Disagree & $\begin{array}{l}\text { Management-ISS disagreement is defined as a dummy variable which equals } 1 \text { if the } \\
\text { recommendation of the management differs from the recommendation of ISS on at } \\
\text { least one proposal in year } t \text {, and } 0 \text { otherwise }\end{array}$ \\
\hline MgmtWin & $\begin{array}{l}\text { Management winning disagreement is defined as a dummy variable which equals } 1 \\
\text { if the voting outcome of a management-ISS disagreement favors the management, } \\
\text { and } 0 \text { otherwise }\end{array}$ \\
\hline CloseVote & $\begin{array}{l}\text { Close vote is defined as an agenda item that passes or fails within a } 5 \% \text { margin of } \\
\text { the voting requirement (Iliev and Lowry 2015) }\end{array}$ \\
\hline SponsorMgmt & $\begin{array}{l}\text { Percentage of proposals sponsored by management is defined as the number of } \\
\text { proposals sponsored by the management divided by the total number of proposals in } \\
\text { year } t\end{array}$ \\
\hline SponsorSh & $\begin{array}{l}\text { Percentage of proposals sponsored by shareholders is defined as the number of } \\
\text { proposals sponsored by the shareholders divided by the total number of proposals in } \\
\text { year } t\end{array}$ \\
\hline$I M R$ & $\begin{array}{l}\text { Inverse Mills Ratio is calculated from the first-stage regression of the Heckman } \\
\text { (1979) model }\end{array}$ \\
\hline PE_Ratio & $\begin{array}{l}\text { The ratio of PE-backed IPOs is defined as the number of PE-backed IPOs divided by } \\
\text { the number of all IPOs in the same 4-digit SIC industry and IPO year }\end{array}$ \\
\hline$P E_{-} I V$ & $\begin{array}{l}\text { Instrumented PE is defined as the predicted value of the first-stage } 2 \text { SLS-IV } \\
\text { regression of } P E \text { on } P E \_ \text {Ratio }\end{array}$ \\
\hline GrLTNOA & $\begin{array}{l}\text { Growth in long-term net operating asset is defined as the sum of change in net PPE, } \\
\text { change in intangibles, and change in other long-term assets from year } t-1 \text { to year } t \text {, } \\
\text { minus the sum of change in other long-term liabilities from year } t-1 \text { to year } t \text { and } \\
\text { depreciation and amortization expense in year } t \text {, scaled by average assets (Fairfield } \\
\text { et al. 2003) }\end{array}$ \\
\hline
\end{tabular}




\section{Figure 1: PE-backed IPO Investment and Restatement Timeline}



Figure 1 presents the IPO timeline for Symmetry Medical Inc. backed by Olympus Partners (a PE firm). Buyout and IPO dates are from form S-1. Olympus Partners' exit date is extracted from form 4 and DEF 14A. The restated period and restatement announcement date are from Audit Analytics. 
Table 1: Descriptive Statistics

Panel A: Summary statistics for PE sponsorship and main dependent variables

\begin{tabular}{lccccccc}
\hline Variable & Mean & SD & Min & p25 & Median & p75 & Max \\
\hline$P E$ & 0.320 & 0.467 & 0.000 & 0.000 & 0.000 & 1.000 & 1.000 \\
Restatement & 0.166 & 0.372 & 0.000 & 0.000 & 0.000 & 0.000 & 1.000 \\
Restate_Material & 0.073 & 0.260 & 0.000 & 0.000 & 0.000 & 0.000 & 1.000 \\
AAER & 0.012 & 0.111 & 0.000 & 0.000 & 0.000 & 0.000 & 1.000 \\
\hline$N$ & 3,146 & & & & & & \\
\hline
\end{tabular}

Panel B: Sample distribution by IPO year

\begin{tabular}{|c|c|c|c|c|c|c|}
\hline \multirow{2}{*}{$\begin{array}{l}\text { IPO } \\
\text { Year }\end{array}$} & \multicolumn{2}{|c|}{ Non-PE } & \multicolumn{2}{|c|}{$\mathrm{PE}$} & \multicolumn{2}{|c|}{ Total } \\
\hline & Frequency & Percentage & Frequency & Percentage & Frequency & Percentage \\
\hline 1998 & 408 & $19.07 \%$ & 45 & $4.47 \%$ & 453 & $14.40 \%$ \\
\hline 1999 & 370 & $17.30 \%$ & 67 & $6.65 \%$ & 437 & $13.89 \%$ \\
\hline 2000 & 231 & $10.80 \%$ & 55 & $5.46 \%$ & 286 & $9.09 \%$ \\
\hline 2001 & 77 & $3.60 \%$ & 46 & $4.57 \%$ & 123 & $3.91 \%$ \\
\hline 2002 & 75 & $3.51 \%$ & 28 & $2.78 \%$ & 103 & $3.27 \%$ \\
\hline 2003 & 57 & $2.66 \%$ & 46 & $4.57 \%$ & 103 & $3.27 \%$ \\
\hline 2004 & 171 & $7.99 \%$ & 73 & $7.25 \%$ & 244 & $7.76 \%$ \\
\hline 2005 & 145 & $6.78 \%$ & 113 & $11.22 \%$ & 258 & $8.20 \%$ \\
\hline 2006 & 95 & $4.44 \%$ & 123 & $12.21 \%$ & 218 & $6.93 \%$ \\
\hline 2007 & 121 & $5.66 \%$ & 66 & $6.55 \%$ & 187 & $5.94 \%$ \\
\hline 2008 & 30 & $1.40 \%$ & 6 & $0.60 \%$ & 36 & $1.14 \%$ \\
\hline 2009 & 28 & $1.31 \%$ & 32 & $3.18 \%$ & 60 & $1.91 \%$ \\
\hline 2010 & 52 & $2.43 \%$ & 58 & $5.76 \%$ & 110 & $3.50 \%$ \\
\hline 2011 & 25 & $1.17 \%$ & 27 & $2.68 \%$ & 52 & $1.65 \%$ \\
\hline 2012 & 47 & $2.20 \%$ & 60 & $5.96 \%$ & 107 & $3.40 \%$ \\
\hline 2013 & 95 & $4.44 \%$ & 71 & $7.05 \%$ & 166 & $5.28 \%$ \\
\hline 2014 & 90 & $4.21 \%$ & 65 & $6.45 \%$ & 155 & $4.93 \%$ \\
\hline 2015 & 22 & $1.03 \%$ & 26 & $2.58 \%$ & 48 & $1.53 \%$ \\
\hline$N$ & 2,139 & $100.00 \%$ & 1,007 & $100.00 \%$ & 3,146 & $100.00 \%$ \\
\hline
\end{tabular}

Panel C: Sample distribution by industry

\begin{tabular}{llccccc}
\hline \multirow{2}{*}{ SIC code } & \multicolumn{1}{c}{ Industry } & \multicolumn{2}{c}{ Non-PE } & & \multicolumn{2}{c}{ PE } \\
\cline { 3 - 4 } \cline { 6 - 7 } & & Frequency & Percentage & & Frequency & Percentage \\
\hline $0100-0999$ & Agriculture, Forestry and Fishing & 7 & $0.33 \%$ & & 6 & $0.60 \%$ \\
$1000-1499$ & Mining & 64 & $2.99 \%$ & & 52 & $5.16 \%$ \\
$1500-1799$ & Construction & 48 & $2.24 \%$ & & 10 & $0.99 \%$ \\
$2000-3999$ & Manufacturing & 561 & $26.23 \%$ & & 324 & $32.17 \%$ \\
$4000-4999$ & Transportation, Communications, & 181 & $8.46 \%$ & & 86 & $8.54 \%$ \\
& Electric, Gas and Sanitary Service & & & & & \\
$5000-5199$ & Wholesale Trade & 67 & $3.13 \%$ & & 42 & $4.17 \%$ \\
$5200-5999$ & Retail Trade & 126 & $5.89 \%$ & & 143 & $14.20 \%$ \\
$6000-6799$ & Finance, Insurance and Real & 519 & $24.26 \%$ & & 95 & $9.43 \%$ \\
& Estate & & & & \\
$7000-8999$ & Services & 566 & $26.46 \%$ & & 249 & $24.73 \%$ \\
\hline$N$ & & 2,139 & $100.00 \%$ & & 1,007 & $100.00 \%$ \\
\hline
\end{tabular}


Panel D: Number of issues by the restatement reason

\begin{tabular}{lccc}
\hline Restatement Reason & Non-PE & PE & Difference \\
\hline Accounting rule application failures & 2.381 & 2.658 & $-0.277^{*}$ \\
Financial fraud, irregularities, and misrepresentations & 0.033 & 0.142 & $-0.109^{* *}$ \\
Material accounting and clerical application errors & 0.054 & 0.058 & -0.004 \\
Other significant issues & 0.145 & 0.163 & -0.018 \\
\hline$N$ & 331 & 190 & \\
\hline
\end{tabular}

Panel E: Restatement distribution by the restatement category

\begin{tabular}{llccc}
\hline Restatement Category & Non-PE & PE & Difference \\
\hline 1 & Depreciation, depletion, or amortization errors & 0.079 & 0.132 & $-0.053^{* *}$ \\
3 & PPE, intangible, or fixed asset (value/diminution) issues & 0.076 & 0.158 & $-0.082^{* * *}$ \\
12 & Liabilities, payables, reserves, and accrual estimate failures & 0.112 & 0.174 & $-0.062^{* *}$ \\
15 & Capital adequacy and calculation issues & 0.000 & 0.021 & $-0.021^{* * *}$ \\
18 & Tax expense/benefit/deferral/other (FAS 109) issues & 0.160 & 0.242 & $-0.082^{* *}$ \\
21 & Lease, SFAS 5, legal, contingency, and commitment issues & 0.066 & 0.137 & $-0.070^{* * *}$ \\
23 & Capitalization of expenditures issues & 0.051 & 0.147 & $-0.096^{* * *}$ \\
42 & Lease, leasehold and FAS 13 (98) only & 0.057 & 0.121 & $-0.064^{* * *}$ \\
44 & Foreign, subsidiary only issues & 0.036 & 0.063 & $-0.027^{*}$ \\
\hline$N$ & & 331 & 190 & \\
\hline
\end{tabular}

$* * *, * *, *$ indicate statistical significance at the $0.01,0.05$, and 0.10 levels, respectively, based on one-tailed tests

This table reports the descriptive statistics for 3,146 firm-years with IPO offering dates between 1998 and 2015. Panel A reports the summary statistics for PE sponsorship and the main dependent variables. Panel B presents the sample distribution by IPO year. Panel C presents the sample distribution by industry. Panel D presents the average number of issues encountered for each restated firm-year by the restatement reason. Panel E presents the portion of restated firm-years with significant differences between PE-backed and non-PE-backed firms by the restatement category. Variables are defined in Appendix A. 
Table 2: Correlations

\begin{tabular}{|c|c|c|c|c|c|c|c|c|c|c|c|c|c|c|c|c|}
\hline & (1) & (2) & (3) & (4) & (5) & (6) & (7) & (8) & (9) & (10) & (11) & (12) & (13) & (14) & (15) & (16) \\
\hline & $P E$ & $\begin{array}{l}\text { Restate } \\
\text { ment }\end{array}$ & $\begin{array}{l}\text { Restate } \\
\text { Material }\end{array}$ & $A A E R$ & Size & $M T B$ & Lev & $R O A$ & SaleGr & Capex & Loss & Cash & Age & $B i g N$ & $\begin{array}{l}\text { NAnaly } \\
\text { st }\end{array}$ & $\begin{array}{l}\text { InstOw } \\
n\end{array}$ \\
\hline (1) & 1 & 0.043 & 0.052 & 0.009 & 0.244 & 0.053 & 0.221 & 0.121 & -0.082 & 0.114 & -0.110 & -0.243 & 0.237 & 0.205 & 0.243 & 0.176 \\
\hline (2) & 0.043 & 1 & 0.629 & 0.182 & 0.065 & -0.028 & 0.036 & -0.045 & 0.002 & 0.009 & 0.032 & -0.049 & 0.033 & 0.027 & 0.045 & 0.044 \\
\hline (3) & 0.052 & 0.629 & 1 & 0.179 & -0.034 & 0.045 & -0.046 & -0.002 & 0.024 & 0.034 & 0.026 & 0.029 & -0.020 & -0.011 & 0.019 & -0.009 \\
\hline (4) & 0.009 & 0.182 & 0.179 & 1 & 0.007 & 0.081 & -0.038 & -0.001 & 0.045 & 0.030 & -0.003 & 0.015 & -0.007 & 0.042 & 0.064 & 0.054 \\
\hline (5) & 0.220 & 0.075 & -0.035 & 0.024 & 1 & -0.101 & 0.428 & 0.239 & 0.010 & -0.103 & -0.339 & -0.333 & 0.368 & 0.297 & 0.640 & 0.519 \\
\hline (6) & -0.052 & -0.049 & 0.018 & 0.093 & -0.187 & 1 & -0.259 & 0.359 & 0.186 & 0.185 & -0.194 & 0.294 & 0.051 & 0.119 & 0.294 & 0.207 \\
\hline (7) & 0.161 & 0.027 & -0.040 & -0.028 & 0.242 & -0.117 & 1 & 0.033 & -0.004 & 0.026 & -0.136 & -0.514 & 0.215 & 0.068 & 0.113 & 0.136 \\
\hline (8) & 0.145 & 0.017 & 0.014 & -0.036 & 0.398 & -0.005 & 0.040 & 1 & 0.256 & 0.085 & -0.826 & -0.066 & 0.242 & 0.154 & 0.371 & 0.322 \\
\hline (9) & -0.105 & -0.025 & 0.003 & 0.032 & -0.070 & 0.126 & -0.036 & -0.077 & 1 & 0.124 & -0.220 & -0.015 & -0.182 & -0.044 & 0.081 & 0.035 \\
\hline (10) & 0.049 & 0.005 & -0.013 & 0.016 & -0.026 & 0.043 & 0.035 & -0.050 & 0.091 & 1 & 0.035 & -0.123 & 0.008 & 0.097 & 0.111 & -0.029 \\
\hline (11) & -0.110 & 0.032 & 0.026 & -0.003 & -0.343 & -0.111 & -0.002 & -0.600 & 0.005 & 0.055 & 1 & 0.169 & -0.245 & -0.091 & -0.346 & -0.305 \\
\hline (12) & -0.249 & -0.040 & 0.024 & 0.016 & -0.367 & 0.289 & -0.211 & -0.230 & 0.041 & -0.165 & 0.198 & 1 & -0.204 & -0.022 & -0.075 & -0.077 \\
\hline (13) & 0.155 & 0.016 & -0.025 & 0.022 & 0.413 & -0.082 & 0.153 & 0.188 & -0.162 & -0.087 & -0.181 & -0.212 & 1 & 0.205 & 0.304 & 0.286 \\
\hline (14) & 0.205 & 0.027 & -0.011 & 0.042 & 0.321 & 0.059 & 0.085 & 0.156 & -0.046 & 0.027 & -0.091 & -0.032 & 0.177 & 1 & 0.348 & 0.303 \\
\hline (15) & 0.182 & 0.030 & 0.009 & 0.068 & 0.640 & 0.158 & 0.057 & 0.282 & -0.032 & 0.070 & -0.308 & -0.124 & 0.258 & 0.304 & 1 & 0.561 \\
\hline (16) & 0.164 & 0.041 & -0.013 & 0.052 & 0.504 & 0.100 & 0.080 & 0.311 & -0.061 & -0.040 & -0.298 & -0.137 & 0.237 & 0.295 & 0.477 & 1 \\
\hline
\end{tabular}

This table reports correlations between PE sponsorship and the main dependent variables and control variables. Pearson (Spearman) correlations are reported below (above) the diagonal. Correlations significant at the $0.05(0.10)$ level are in bold (italic). Continuous variables are winsorized at 1 and 99 percent.

Variables are defined in Appendix A. 
Table 3: Summary Statistics after Entropy Balancing

\begin{tabular}{|c|c|c|c|c|c|c|c|c|c|c|c|}
\hline & (1) & (2) & (3) & (4) & (5) & (6) & (7) & (8) & (9) & $(10)$ & (11) \\
\hline Variable & $\begin{array}{c}\text { Mean_ } \\
\text { PE }\end{array}$ & $\begin{array}{l}\text { Mean_- } \\
\text { Non_Pre }\end{array}$ & $\begin{array}{c}\text { Mean_ } \\
\text { Diff }\end{array}$ & $\begin{array}{c}\text { Mean_- } \\
\text { Non_Post }\end{array}$ & $\begin{array}{c}\text { Mean_- } \\
\text { Diff }\end{array}$ & Var_PE & $\begin{array}{c}\text { Var_- } \\
\text { Non_Pre }\end{array}$ & $\begin{array}{c}\text { Var_- } \\
\text { Non_Post }\end{array}$ & Skew_PE & $\begin{array}{c}\text { Skew_- } \\
\text { Non_Pre }\end{array}$ & $\begin{array}{c}\text { Skew_- } \\
\text { Non_Post }\end{array}$ \\
\hline Size & 6.798 & 5.895 & $-0.903^{* * *}$ & 6.798 & 0.000 & 1.943 & 4.243 & 1.943 & 0.177 & 0.374 & 0.177 \\
\hline$M T B$ & 1.769 & 1.929 & $0.160^{* * *}$ & 1.769 & 0.000 & 1.290 & 2.449 & 1.290 & 3.216 & 2.337 & 3.217 \\
\hline Lev & 1.882 & 0.941 & $-0.941^{* * *}$ & 1.881 & 0.000 & 10.782 & 5.530 & 10.782 & 3.541 & 5.592 & 3.541 \\
\hline$R O A$ & 0.007 & -0.069 & $-0.077^{* * *}$ & 0.007 & 0.000 & 0.023 & 0.077 & 0.023 & -3.686 & -2.495 & -3.686 \\
\hline SaleGr & 0.144 & 0.303 & $0.159^{* * *}$ & 0.144 & 0.000 & 0.175 & 0.645 & 0.175 & 5.926 & 3.829 & 5.926 \\
\hline Capex & 0.062 & 0.053 & $-0.008^{* * *}$ & 0.062 & 0.000 & 0.006 & 0.006 & 0.006 & 2.618 & 2.703 & 2.618 \\
\hline Loss & 0.296 & 0.410 & $0.115^{* * *}$ & 0.296 & 0.000 & 0.209 & 0.242 & 0.209 & 0.894 & 0.364 & 0.893 \\
\hline Cash & 0.114 & 0.228 & $0.114^{* * *}$ & 0.114 & 0.000 & 0.020 & 0.054 & 0.020 & 2.370 & 1.154 & 2.370 \\
\hline Age & 36.405 & 26.234 & $-10.388^{* * *}$ & 36.404 & 0.000 & 930.766 & 911.338 & 930.730 & 1.395 & 2.279 & 1.395 \\
\hline IPO_Age & 3.094 & 3.315 & $0.220^{* * *}$ & 3.094 & 0.000 & 1.107 & 1.208 & 1.107 & 0.513 & 0.228 & 0.513 \\
\hline$B i g N$ & 0.918 & 0.741 & $-0.177^{* * *}$ & 0.918 & 0.000 & 0.076 & 0.192 & 0.076 & -3.037 & -1.100 & -3.036 \\
\hline NAnalyst & 7.103 & 5.161 & $-1.942^{* * *}$ & 7.103 & 0.000 & 20.490 & 25.634 & 20.490 & 0.965 & 1.271 & 0.965 \\
\hline InstOwn & 0.527 & 0.419 & $-0.108^{* * *}$ & 0.527 & 0.000 & 0.075 & 0.101 & 0.075 & 0.033 & 0.364 & 0.033 \\
\hline Ch_Rec & -0.010 & -0.016 & $-0.006^{* * *}$ & -0.010 & 0.000 & 0.002 & 0.004 & 0.002 & -1.796 & -1.729 & -1.796 \\
\hline$C h \_I n v$ & -0.007 & -0.010 & $-0.003^{*}$ & -0.007 & 0.000 & 0.001 & 0.002 & 0.001 & -2.294 & -2.557 & -2.294 \\
\hline$C h \_E m p$ & 0.106 & 0.148 & $0.042^{* * *}$ & 0.106 & 0.000 & 0.088 & 0.162 & 0.088 & 3.100 & 2.342 & 3.100 \\
\hline$C h \_R O A$ & 0.003 & 0.000 & -0.003 & 0.003 & 0.000 & 0.018 & 0.038 & 0.018 & 0.424 & 0.620 & 0.424 \\
\hline$C h \_C s$ & 0.141 & 0.274 & $0.134^{* * *}$ & 0.141 & 0.000 & 0.192 & 0.550 & 0.192 & 4.978 & 3.113 & 4.978 \\
\hline$N$ & 1,007 & 2,139 & 3,146 & 2,139 & 3,146 & 1,007 & 2,139 & 2,139 & 1,007 & 2,139 & 2,139 \\
\hline
\end{tabular}

$* * *, * *, *$ indicate statistical significance at the $0.01,0.05$, and 0.10 levels, respectively, based on two-tailed tests

This table reports the summary statistics for the entropy-balanced sample. Columns (1), (6), and (9) present the mean, variance, and skewness for PE-backed firm-years, respectively. Columns (2), (7), and (10) present the mean, variance, and skewness for non-PE-backed firm-years before entropy balancing, respectively. Columns (4), (8), and (11) present the mean, variance, and skewness for non-PE-backed firm-years after entropy balancing, respectively. Column (3) compares the difference in mean between PE-backed firm-years and non-PE-backed firm-years before entropy balancing. Column (5) compares the difference in mean between PE-backed firm-years and non-PE-backed firm-years after entropy balancing. Continuous variables are winsorized at 1 and 99 percent, based on standard errors clustered at the firm level. Variables are defined in Appendix A. 
Table 4: PE Ownership and Financial Misreporting

Panel A: Restatement and AAER: PE-backed firms vs. non-PE-backed firms

\begin{tabular}{|c|c|c|c|c|}
\hline Dependent variable & $\begin{array}{c}\text { (1) } \\
\text { Restatement }\end{array}$ & $\begin{array}{c}\text { (2) } \\
\text { Restate_Material }\end{array}$ & $\begin{array}{c}\text { (3) } \\
\text { Restate_Period }\end{array}$ & $\begin{array}{c}(4) \\
A A E R\end{array}$ \\
\hline$P E$ & $\begin{array}{l}0.492^{* *} \\
(2.15)\end{array}$ & $\begin{array}{c}0.971^{* * * *} \\
(3.00)\end{array}$ & $\begin{array}{c}0.256^{* *} \\
(2.58)\end{array}$ & $\begin{array}{l}2.241^{* * *} \\
(2.27)\end{array}$ \\
\hline Size & $\begin{array}{l}0.171 \\
(1.54)\end{array}$ & $\begin{array}{l}-0.079 \\
(0.60)\end{array}$ & $\begin{array}{l}0.025 \\
(0.44)\end{array}$ & $\begin{array}{c}1.077^{* * * *} \\
(2.78)\end{array}$ \\
\hline MTB & $\begin{array}{l}0.066 \\
(0.63)\end{array}$ & $\begin{array}{l}0.003 \\
(0.02)\end{array}$ & $\begin{array}{c}0.165^{* * * *} \\
(3.10)\end{array}$ & $\begin{array}{l}0.370 \\
(0.90)\end{array}$ \\
\hline Lev & $\begin{array}{l}0.040 \\
(1.46)\end{array}$ & $\begin{array}{l}-0.020 \\
(0.42)\end{array}$ & $\begin{array}{l}0.024 \\
(1.07)\end{array}$ & $\begin{array}{l}-0.080 \\
(0.68)\end{array}$ \\
\hline$R O A$ & $\begin{array}{l}0.688 \\
(1.03)\end{array}$ & $\begin{array}{l}0.757 \\
(0.92)\end{array}$ & $\begin{array}{l}0.058 \\
(0.11)\end{array}$ & $\begin{array}{l}-3.956 \\
(0.99)\end{array}$ \\
\hline SaleGr & $\begin{array}{l}0.054 \\
(0.15)\end{array}$ & $\begin{array}{l}0.405 \\
(1.11)\end{array}$ & $\begin{array}{l}-0.172 \\
(1.50)\end{array}$ & $\begin{array}{l}0.171 \\
(0.11)\end{array}$ \\
\hline Capex & $\begin{array}{l}-0.155 \\
(0.11)\end{array}$ & $\begin{array}{l}-1.600 \\
(0.59)\end{array}$ & $\begin{array}{l}-0.037 \\
(0.04)\end{array}$ & $\begin{array}{l}4.174 \\
(0.57)\end{array}$ \\
\hline Loss & $\begin{array}{c}0.573^{* * * *} \\
(2.83)\end{array}$ & $\begin{array}{l}0.376 \\
(1.33)\end{array}$ & $\begin{array}{l}-0.029 \\
(0.25)\end{array}$ & $\begin{array}{l}-0.231 \\
(0.23)\end{array}$ \\
\hline Cash & $\begin{array}{l}0.885 \\
(1.10)\end{array}$ & $\begin{array}{l}1.561 \\
(1.50)\end{array}$ & $\begin{array}{l}0.551 \\
(1.24)\end{array}$ & $\begin{array}{l}4.462^{*} \\
(1.65)\end{array}$ \\
\hline Age & $\begin{array}{l}-0.001 \\
(0.26)\end{array}$ & $\begin{array}{l}-0.001 \\
(0.19)\end{array}$ & $\begin{array}{l}-0.002 \\
(0.86)\end{array}$ & $\begin{array}{l}-0.015 \\
(0.85)\end{array}$ \\
\hline IPO_Age & $\begin{array}{l}-0.098 \\
(1.36)\end{array}$ & $\begin{array}{l}-0.033 \\
(0.31)\end{array}$ & $\begin{array}{l}-0.016 \\
(0.31)\end{array}$ & $\begin{array}{l}-0.475 \\
(1.48)\end{array}$ \\
\hline$B i g N$ & $\begin{array}{l}-0.229 \\
(0.60)\end{array}$ & $\begin{array}{c}-1.252^{* * * *} \\
(2.74)\end{array}$ & $\begin{array}{l}-0.117 \\
(0.88)\end{array}$ & $\begin{array}{l}0.321 \\
(0.19)\end{array}$ \\
\hline NAnalyst & $\begin{array}{c}-0.061^{* *} \\
(2.06)\end{array}$ & $\begin{array}{l}0.023 \\
(0.65)\end{array}$ & $\begin{array}{l}0.013 \\
(0.89)\end{array}$ & $\begin{array}{l}-0.025 \\
(0.14)\end{array}$ \\
\hline InstOwn & $\begin{array}{l}0.891^{* *} \\
(2.23)\end{array}$ & $\begin{array}{l}0.308 \\
(0.63)\end{array}$ & $\begin{array}{l}-0.309 \\
(1.65)\end{array}$ & $\begin{array}{l}6.655^{* * * *} \\
(5.09)\end{array}$ \\
\hline Ch_Rec & $\begin{array}{l}-1.407 \\
(0.84)\end{array}$ & $\begin{array}{c}-4.540^{*} \\
(1.78)\end{array}$ & $\begin{array}{l}-0.578 \\
(0.66)\end{array}$ & $\begin{array}{l}-6.266 \\
(0.75)\end{array}$ \\
\hline$C h \_I n v$ & $\begin{array}{l}4.092^{*} \\
(1.87)\end{array}$ & $\begin{array}{c}7.682^{* * * *} \\
(2.83)\end{array}$ & $\begin{array}{c}-1.976^{*} \\
(1.76)\end{array}$ & $\begin{array}{c}21.159^{* * *} \\
(2.03)\end{array}$ \\
\hline Ch_Emp & $\begin{array}{c}-0.236 \\
(0.93)\end{array}$ & $\begin{array}{l}0.496 \\
(1.51)\end{array}$ & $\begin{array}{c}-0.262^{*} \\
(1.75)\end{array}$ & $\begin{array}{l}-0.176 \\
(0.15)\end{array}$ \\
\hline$C h \_R O A$ & $\begin{array}{l}-0.680 \\
(1.12)\end{array}$ & $\begin{array}{l}-0.495 \\
(0.65)\end{array}$ & $\begin{array}{l}0.195 \\
(0.32)\end{array}$ & $\begin{array}{l}0.290 \\
(0.16)\end{array}$ \\
\hline$C h \_C s$ & $\begin{array}{l}0.038 \\
(0.10)\end{array}$ & $\begin{array}{l}-0.476 \\
(1.57)\end{array}$ & $\begin{array}{c}-0.008 \\
(0.08)\end{array}$ & $\begin{array}{l}-0.287 \\
(0.16)\end{array}$ \\
\hline Intercept & $\begin{array}{c}-2.782^{* * * *} \\
(3.15)\end{array}$ & $\begin{array}{l}-0.266 \\
(0.30)\end{array}$ & $\begin{array}{c}6.385^{* * * *} \\
(17.93)\end{array}$ & $\begin{array}{c}-16.799^{* * * *} \\
(5.33)\end{array}$ \\
\hline Industry FE & Yes & Yes & Yes & Yes \\
\hline IPO year FE & Yes & Yes & Yes & Yes \\
\hline 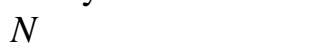 & 3,146 & 3,146 & 521 & 3,146 \\
\hline Pseudo/Adjusted $R^{2}$ & 0.168 & 0.193 & 0.394 & 0.483 \\
\hline
\end{tabular}


Panel B: PE-backed firms vs. non-PE-backed firms by PE firms' presence

\begin{tabular}{|c|c|c|c|c|}
\hline Dependent variable & $\begin{array}{c}\text { (1) } \\
\text { Restatement }\end{array}$ & $\begin{array}{c}(2) \\
\text { Restate_Material }\end{array}$ & $\begin{array}{c}\text { (3) } \\
\text { Restate_Period }\end{array}$ & $\begin{array}{c}(4) \\
A A E R\end{array}$ \\
\hline \multirow[t]{2}{*}{ Before_Exit } & $0.366^{*}$ & $0.961^{* * *}$ & $0.317^{* * *}$ & $2.104^{* * *}$ \\
\hline & (1.67) & $(3.36)$ & $(3.14)$ & $(2.65)$ \\
\hline \multirow[t]{2}{*}{ After_Exit } & 0.004 & 0.335 & 0.154 & 1.254 \\
\hline & $(0.02)$ & $(1.00)$ & $(1.23)$ & (1.53) \\
\hline \multirow[t]{2}{*}{ Size } & 0.011 & -0.107 & -0.041 & 0.317 \\
\hline & $(0.11)$ & $(1.01)$ & $(0.77)$ & $(0.95)$ \\
\hline \multirow[t]{2}{*}{$M T B$} & -0.049 & 0.025 & $0.171^{* * *}$ & 0.266 \\
\hline & $(0.54)$ & $(0.24)$ & $(2.88)$ & $(1.40)$ \\
\hline \multirow[t]{2}{*}{ Lev } & 0.029 & -0.013 & 0.030 & -0.036 \\
\hline & $(1.29)$ & $(0.37)$ & $(1.48)$ & $(0.78)$ \\
\hline \multirow[t]{2}{*}{$R O A$} & 0.476 & -0.317 & -0.465 & $-4.519^{* * *}$ \\
\hline & $(0.79)$ & $(0.52)$ & $(1.16)$ & $(3.09)$ \\
\hline \multirow[t]{2}{*}{ SaleGr } & -0.183 & 0.198 & -0.102 & -0.006 \\
\hline & $(0.58)$ & $(0.97)$ & $(1.04)$ & $(0.01)$ \\
\hline \multirow[t]{2}{*}{ Capex } & 0.670 & 0.885 & 0.109 & 0.706 \\
\hline & $(0.53)$ & $(0.49)$ & $(0.14)$ & $(0.20)$ \\
\hline \multirow[t]{2}{*}{ Loss } & $0.350^{* * *}$ & 0.134 & -0.030 & -0.016 \\
\hline & $(2.01)$ & $(0.59)$ & $(0.26)$ & $(0.03)$ \\
\hline \multirow[t]{2}{*}{ Cash } & 0.967 & 1.146 & 0.405 & 1.123 \\
\hline & (1.64) & (1.44) & $(1.10)$ & $(0.42)$ \\
\hline \multirow[t]{2}{*}{ Age } & -0.001 & -0.003 & -0.001 & -0.002 \\
\hline & $(0.37)$ & $(0.47)$ & $(0.38)$ & $(0.23)$ \\
\hline \multirow[t]{2}{*}{ IPO_Age } & -0.064 & 0.013 & -0.033 & -0.129 \\
\hline & $(1.02)$ & $(0.15)$ & $(0.71)$ & $(0.51)$ \\
\hline \multirow[t]{2}{*}{ Intercept } & $-2.303^{* *}$ & -1.036 & $6.493^{* * *}$ & $-10.955^{* * *}$ \\
\hline & $(2.57)$ & $(1.27)$ & $(18.44)$ & $(4.20)$ \\
\hline$\chi^{2}$ or F statistic: & 3.14 & 4.99 & 2.17 & 1.45 \\
\hline Before_Exit $>$ After_Exit & $(p=0.038)$ & $(p=0.013)$ & $(p=0.071)$ & $(\mathrm{p}=0.114)$ \\
\hline Industry FE & Yes & Yes & Yes & Yes \\
\hline IPO year FE & Yes & Yes & Yes & Yes \\
\hline Additional Controls & Yes & Yes & Yes & Yes \\
\hline$N$ & 3,910 & 3,910 & 643 & 3,910 \\
\hline Pseudo $R^{2}$ & 0.111 & 0.136 & 0.278 & 0.330 \\
\hline
\end{tabular}

$* * *, * *, *$ indicate statistical significance at the $0.01,0.05$, and 0.10 levels, respectively, based on two-tailed tests

Panel A presents the results regarding the effect of PE firm on portfolio firm's financial misreporting. Columns (1) to (4) report the impact of PE firms on restatement likelihood, material restatement likelihood, the length of the restated period, and AAER likelihood, respectively. Panel B presents the results regarding the impact of PE firms on portfolio firm's financial misreporting during years when they do not exit and when they exit from the portfolio firms. Columns (1) to (4) report the impact of PE firms' presence on restatement likelihood, material restatement likelihood, the length of the restated period, and AAER likelihood, respectively. Continuous variables are winsorized at 1 and 99 percent. Absolute $t$ statistics or $z$ statistics are in parentheses, based on standard errors clustered at the firm level. Variables are defined in Appendix A. 
Table 5: PE Ownership and Pursuit of Profits

\begin{tabular}{|c|c|c|c|c|}
\hline Dependent variable & $\begin{array}{c}(1) \\
\text { Restatement }\end{array}$ & $\begin{array}{c}(2) \\
\text { Restate_Material }\end{array}$ & $\begin{array}{c}\text { (3) } \\
\text { Restate_Period }\end{array}$ & $\begin{array}{c}(4) \\
A A E R\end{array}$ \\
\hline Large_Sell & $\begin{array}{l}0.500^{*} \\
(1.82)\end{array}$ & $\begin{array}{c}1.222^{* * *} \\
(3.40)\end{array}$ & $\begin{array}{c}0.339^{* * *} \\
(3.16)\end{array}$ & $\begin{array}{l}2.224^{* *} \\
(2.47)\end{array}$ \\
\hline Non_Large_Sell & $\begin{array}{c}0.488^{* * *} \\
(2.06)\end{array}$ & $\begin{array}{l}0.845^{* *} \\
(2.44)\end{array}$ & $\begin{array}{l}0.208^{*} \\
(1.83)\end{array}$ & $\begin{array}{l}2.263^{*} \\
(1.89)\end{array}$ \\
\hline Size & $\begin{array}{l}0.171 \\
(1.54)\end{array}$ & $\begin{array}{l}-0.074 \\
(0.57)\end{array}$ & $\begin{array}{l}0.026 \\
(0.45)\end{array}$ & $\begin{array}{c}1.078^{* * * *} \\
(2.77)\end{array}$ \\
\hline MTB & $\begin{array}{l}0.065 \\
(0.62)\end{array}$ & $\begin{array}{l}-0.003 \\
(0.02)\end{array}$ & $\begin{array}{c}0.168^{* * * *} \\
(3.15)\end{array}$ & $\begin{array}{l}0.370 \\
(0.90)\end{array}$ \\
\hline Lev & $\begin{array}{l}0.040 \\
(1.46)\end{array}$ & $\begin{array}{l}-0.018 \\
(0.37)\end{array}$ & $\begin{array}{l}0.023 \\
(1.02)\end{array}$ & $\begin{array}{l}-0.081 \\
(0.65)\end{array}$ \\
\hline$R O A$ & $\begin{array}{l}0.688 \\
(1.03)\end{array}$ & $\begin{array}{l}0.784 \\
(0.95)\end{array}$ & $\begin{array}{l}0.042 \\
(0.08)\end{array}$ & $\begin{array}{l}-3.964 \\
(0.98)\end{array}$ \\
\hline SaleGr & $\begin{array}{l}0.054 \\
(0.15)\end{array}$ & $\begin{array}{l}0.398 \\
(1.10)\end{array}$ & $\begin{array}{l}-0.182 \\
(1.59)\end{array}$ & $\begin{array}{l}0.171 \\
(0.11)\end{array}$ \\
\hline Capex & $\begin{array}{l}-0.151 \\
(0.10)\end{array}$ & $\begin{array}{l}-1.419 \\
(0.54)\end{array}$ & $\begin{array}{l}0.097 \\
(0.11)\end{array}$ & $\begin{array}{l}4.195 \\
(0.57)\end{array}$ \\
\hline Loss & $\begin{array}{c}0.573^{* * *} \\
(2.83)\end{array}$ & $\begin{array}{l}0.412 \\
(1.44)\end{array}$ & $\begin{array}{l}-0.028 \\
(0.25)\end{array}$ & $\begin{array}{l}-0.240 \\
(0.22)\end{array}$ \\
\hline Cash & $\begin{array}{l}0.888 \\
(1.10)\end{array}$ & $\begin{array}{l}1.632 \\
(1.59)\end{array}$ & $\begin{array}{l}0.550 \\
(1.26)\end{array}$ & $\begin{array}{l}4.469^{*} \\
(1.66)\end{array}$ \\
\hline Age & $\begin{array}{l}-0.001 \\
(0.26)\end{array}$ & $\begin{array}{l}-0.001 \\
(0.19)\end{array}$ & $\begin{array}{r}-0.002 \\
(0.73)\end{array}$ & $\begin{array}{l}-0.015 \\
(0.85)\end{array}$ \\
\hline IPO_Age & $\begin{array}{l}-0.098 \\
(1.37)\end{array}$ & $\begin{array}{l}-0.024 \\
(0.23)\end{array}$ & $\begin{array}{r}-0.013 \\
(0.27)\end{array}$ & $\begin{array}{l}-0.474 \\
(1.45)\end{array}$ \\
\hline Intercept & $\begin{array}{c}-2.780^{* * * *} \\
(3.14) \\
\end{array}$ & $\begin{array}{l}-0.202 \\
(0.22) \\
\end{array}$ & $\begin{array}{l}6.379^{* * *} \\
(17.88)\end{array}$ & $\begin{array}{c}-16.835^{* * *} \\
(5.06)\end{array}$ \\
\hline $\begin{array}{l}\chi^{2} \text { or F statistic: } \\
\text { Large_Sell }>\text { Non_Large_Sell }\end{array}$ & $\begin{array}{c}0.00 \\
(\mathrm{p}=0.478)\end{array}$ & $\begin{array}{c}1.78 \\
(\mathrm{p}=0.091)\end{array}$ & $\begin{array}{c}1.47 \\
(\mathrm{p}=0.113)\end{array}$ & $\begin{array}{c}0.00 \\
(\mathrm{p}=0.477)\end{array}$ \\
\hline Industry FE & Yes & Yes & Yes & Yes \\
\hline IPO year FE & Yes & Yes & Yes & Yes \\
\hline Additional Controls & Yes & Yes & Yes & Yes \\
\hline$N$ & 3,146 & 3,146 & 521 & 3,146 \\
\hline Pseudo/Adjusted $R^{2}$ & 0.168 & 0.195 & 0.395 & 0.483 \\
\hline
\end{tabular}

$* * *, * *, *$ indicate statistical significance at the $0.01,0.05$, and 0.10 levels, respectively, based on two-tailed tests

This table presents the results regarding the impact of PE firms on portfolio firms' financial misreporting during years with large disposal of equity ownership. Columns (1) to (4) report the impact of PE firms' large sell on restatement likelihood, material restatement likelihood, the length of the restated period, and AAER likelihood, respectively. Continuous variables are winsorized at 1 and 99 percent. Absolute $t$ statistics or $z$ statistics are in parentheses, based on standard errors clustered at the firm level. Variables are defined in Appendix A. 
Table 6: PE Ownership and Captured Board and Executives

Panel A: PE-backed firms vs. non-PE-backed firms by PE ownership

\begin{tabular}{|c|c|c|c|c|}
\hline Dependent variable & $\begin{array}{c}\text { (1) } \\
\text { Restatement }\end{array}$ & $\begin{array}{c}(2) \\
\text { Restate_Material }\end{array}$ & $\begin{array}{c}\text { (3) } \\
\text { Restate_Period }\end{array}$ & $\begin{array}{c}(4) \\
A A E R\end{array}$ \\
\hline$P E \_O w n$ & 0.006 & $0.013^{* *}$ & $0.005^{* * * *}$ & $0.054^{* * * *}$ \\
\hline Size & $\begin{array}{l}0.158 \\
(1.41)\end{array}$ & $\begin{array}{l}-0.117 \\
(0.86)\end{array}$ & $\begin{array}{l}0.019 \\
(0.32)\end{array}$ & $\begin{array}{l}0.991^{* *} \\
(2.41)\end{array}$ \\
\hline MTB & $\begin{array}{l}0.063 \\
(0.61)\end{array}$ & $\begin{array}{l}0.010 \\
(0.08)\end{array}$ & $\begin{array}{c}0.164^{* * * *} \\
(3.11)\end{array}$ & $\begin{array}{l}0.368 \\
(1.00)\end{array}$ \\
\hline Lev & $\begin{array}{l}0.037 \\
(1.38)\end{array}$ & $\begin{array}{l}-0.026 \\
(0.52)\end{array}$ & $\begin{array}{l}0.026 \\
(1.19)\end{array}$ & $\begin{array}{l}-0.118 \\
(0.69)\end{array}$ \\
\hline$R O A$ & $\begin{array}{l}0.688 \\
(1.04)\end{array}$ & $\begin{array}{l}0.761 \\
(1.01)\end{array}$ & $\begin{array}{l}0.132 \\
(0.26)\end{array}$ & $\begin{array}{l}-4.376 \\
(1.26)\end{array}$ \\
\hline SaleGr & $\begin{array}{l}0.042 \\
(0.12)\end{array}$ & $\begin{array}{l}0.400 \\
(1.11)\end{array}$ & $\begin{array}{l}-0.133 \\
(1.21)\end{array}$ & $\begin{array}{l}0.287 \\
(0.29)\end{array}$ \\
\hline Capex & $\begin{array}{l}0.007 \\
(0.00)\end{array}$ & $\begin{array}{r}-1.523 \\
(0.53)\end{array}$ & $\begin{array}{l}-0.076 \\
(0.09)\end{array}$ & $\begin{array}{l}7.394 \\
(0.99)\end{array}$ \\
\hline Loss & $\begin{array}{c}0.571^{* * *} \\
(2.79)\end{array}$ & $\begin{array}{l}0.371 \\
(1.31)\end{array}$ & $\begin{array}{l}-0.030 \\
(0.26)\end{array}$ & $\begin{array}{l}-0.329 \\
(0.29)\end{array}$ \\
\hline Cash & $\begin{array}{l}0.846 \\
(1.04)\end{array}$ & $\begin{array}{l}1.441 \\
(1.39)\end{array}$ & $\begin{array}{l}0.654 \\
(1.56)\end{array}$ & $\begin{array}{l}4.498^{*} \\
(1.79)\end{array}$ \\
\hline Age & $\begin{array}{l}-0.001 \\
(0.26)\end{array}$ & $\begin{array}{r}-0.001 \\
(0.17)\end{array}$ & $\begin{array}{l}-0.002 \\
(0.95)\end{array}$ & $\begin{array}{l}-0.013 \\
(0.79)\end{array}$ \\
\hline IPO_Age & $\begin{array}{l}-0.085 \\
(1.16)\end{array}$ & $\begin{array}{l}-0.010 \\
(0.09)\end{array}$ & $\begin{array}{l}-0.003 \\
(0.07)\end{array}$ & $\begin{array}{l}-0.210 \\
(0.60)\end{array}$ \\
\hline$B i g N$ & $\begin{array}{l}-0.212 \\
(0.54)\end{array}$ & $\begin{array}{c}-1.215^{* * * *} \\
(2.61)\end{array}$ & $\begin{array}{r}-0.138 \\
(1.04)\end{array}$ & $\begin{array}{l}-0.471 \\
(0.34)\end{array}$ \\
\hline NAnalyst & $\begin{array}{l}-0.058^{*} \\
(1.92)\end{array}$ & $\begin{array}{l}0.028 \\
(0.81)\end{array}$ & $\begin{array}{l}0.013 \\
(0.93)\end{array}$ & $\begin{array}{l}0.035 \\
(0.23)\end{array}$ \\
\hline InstOwn & $\begin{array}{c}0.937^{* *} \\
(2.38)\end{array}$ & $\begin{array}{l}0.446 \\
(0.89)\end{array}$ & $\begin{array}{r}-0.263 \\
(1.37)\end{array}$ & $\begin{array}{c}7.795^{* * *} \\
(5.68)\end{array}$ \\
\hline Intercept & $\begin{array}{l}-2.657^{* * * *} \\
(2.95)\end{array}$ & $\begin{array}{l}0.059 \\
(0.07)\end{array}$ & $\begin{array}{l}6.407^{* * * *} \\
(18.21)\end{array}$ & $\begin{array}{c}-16.584^{* * *} \\
(5.19)\end{array}$ \\
\hline Industry FE & Yes & Yes & Yes & Yes \\
\hline IPO year FE & Yes & Yes & Yes & Yes \\
\hline Additional Controls & Yes & Yes & Yes & Yes \\
\hline$N$ & 3,146 & 3,146 & 521 & 3,146 \\
\hline Pseudo/Adjusted $R^{2}$ & 0.164 & 0.182 & 0.393 & 0.505 \\
\hline
\end{tabular}


Panel B: PE-backed firms vs. non-PE-backed firms by PE firm size

\begin{tabular}{|c|c|c|c|c|}
\hline Dependent variable & $\begin{array}{c}(1) \\
\text { Restatement }\end{array}$ & $\begin{array}{c}(2) \\
\text { Restate_Material }\end{array}$ & $\begin{array}{c}\text { (3) } \\
\text { Restate_Period }\end{array}$ & $\begin{array}{c}(4) \\
A A E R\end{array}$ \\
\hline \multirow[t]{2}{*}{ PE_Large } & $0.505^{*}$ & $0.819^{* *}$ & $0.307^{* *}$ & $1.900^{*}$ \\
\hline & (1.89) & $(2.01)$ & $(2.49)$ & $(1.71)$ \\
\hline \multirow[t]{2}{*}{ PE_Small } & $0.479^{*}$ & $1.099^{* * * *}$ & 0.187 & $3.465^{* *}$ \\
\hline & $(1.80)$ & $(3.22)$ & (1.58) & (2.19) \\
\hline \multirow[t]{2}{*}{ Size } & 0.170 & -0.068 & 0.025 & $1.171^{* * *}$ \\
\hline & $(1.50)$ & $(0.51)$ & $(0.43)$ & $(2.84)$ \\
\hline \multirow[t]{2}{*}{$M T B$} & 0.065 & 0.010 & $0.164^{* * *}$ & 0.441 \\
\hline & $(0.62)$ & $(0.07)$ & $(3.08)$ & $(1.02)$ \\
\hline \multirow[t]{2}{*}{ Lev } & 0.040 & -0.019 & 0.022 & -0.063 \\
\hline & $(1.46)$ & $(0.39)$ & $(1.00)$ & $(0.47)$ \\
\hline \multirow[t]{2}{*}{$R O A$} & 0.691 & 0.748 & 0.105 & -4.441 \\
\hline & (1.04) & $(0.91)$ & $(0.20)$ & $(1.24)$ \\
\hline \multirow[t]{2}{*}{ SaleGr } & 0.052 & 0.402 & -0.177 & -0.049 \\
\hline & $(0.14)$ & (1.09) & (1.54) & $(0.04)$ \\
\hline \multirow[t]{2}{*}{ Capex } & -0.156 & -1.631 & -0.132 & 2.549 \\
\hline & $(0.11)$ & $(0.60)$ & $(0.15)$ & $(0.30)$ \\
\hline \multirow[t]{2}{*}{ Loss } & $0.574^{* * *}$ & 0.369 & -0.029 & 0.153 \\
\hline & $(2.84)$ & $(1.31)$ & $(0.25)$ & $(0.13)$ \\
\hline \multirow[t]{2}{*}{ Cash } & 0.887 & 1.513 & 0.577 & $5.166^{* *}$ \\
\hline & (1.10) & $(1.45)$ & (1.34) & $(2.06)$ \\
\hline \multirow[t]{2}{*}{ Age } & -0.001 & -0.001 & -0.002 & -0.004 \\
\hline & $(0.26)$ & $(0.15)$ & $(0.98)$ & $(0.19)$ \\
\hline \multirow[t]{2}{*}{ IPO_Age } & -0.098 & -0.035 & -0.015 & -0.523 \\
\hline & $(1.36)$ & $(0.33)$ & $(0.30)$ & $(1.54)$ \\
\hline \multirow[t]{2}{*}{$B i g N$} & -0.231 & $-1.219^{* * *}$ & -0.127 & -0.495 \\
\hline & $(0.60)$ & $(2.67)$ & $(0.96)$ & $(0.28)$ \\
\hline \multirow[t]{2}{*}{ NAnalyst } & $-0.061^{* *}$ & 0.021 & 0.013 & -0.018 \\
\hline & $(2.04)$ & $(0.59)$ & $(0.92)$ & $(0.11)$ \\
\hline \multirow[t]{2}{*}{ InstOwn } & $0.893^{* *}$ & 0.309 & $-0.328^{*}$ & $7.417^{* * * *}$ \\
\hline & $(2.24)$ & $(0.63)$ & $(1.73)$ & $(4.51)$ \\
\hline \multirow[t]{2}{*}{ Intercept } & $-2.783^{* * *}$ & -0.245 & $6.388^{* * * *}$ & $-17.964^{* * * *}$ \\
\hline & $(3.16)$ & $(0.27)$ & $(17.95)$ & $(4.79)$ \\
\hline$\chi^{2}$ or F statistic: & 0.01 & 0.56 & 3.71 & 1.41 \\
\hline$P E \_$Large $>P E \_$Small & $(\mathrm{p}=0.461)$ & $(\mathrm{p}=0.227)$ & $(\mathrm{p}=0.028)$ & $(\mathrm{p}=0.118)$ \\
\hline Industry FE & Yes & Yes & Yes & Yes \\
\hline IPO year FE & Yes & Yes & Yes & Yes \\
\hline Additional Controls & Yes & Yes & Yes & Yes \\
\hline$N$ & 3,146 & 3,146 & 521 & 3,146 \\
\hline Pseudo/Adjusted $R^{2}$ & 0.168 & 0.194 & 0.394 & 0.495 \\
\hline
\end{tabular}


Panel C: Board characteristics for PE-backed firms vs. non-PE-backed firms

\begin{tabular}{lccc}
\hline Variable & Non-PE & PE & Difference \\
\hline BodSize & 9.233 & 9.039 & 0.195 \\
Independence & 5.279 & 5.363 & -0.084 \\
Independent & 0.757 & 0.750 & 0.007 \\
CeoChair & 0.522 & 0.425 & $0.097^{* * *}$ \\
\hline$N$ & 1,218 & 779 & \\
\hline
\end{tabular}

Panel D: Vote records for PE-backed firms vs. non-PE-backed firms

\begin{tabular}{lccc}
\hline Variable & Non-PE & PE & Difference \\
\hline Disagree & 0.494 & 0.656 & $-0.162^{* * * *}$ \\
MgmtWin & 0.901 & 0.951 & $-0.050^{* * * *}$ \\
CloseVote & 0.019 & 0.004 & $0.015^{* *}$ \\
SponsorMgmt & 0.992 & 0.998 & $-0.006^{* * * *}$ \\
SponsorSh & 0.008 & 0.002 & $0.006^{* * *}$ \\
\hline$N$ & 788 & 686 & \\
\hline
\end{tabular}

Panel E: Dissenting proposal agenda descriptions for PE-backed firms vs. non-PE-backed firms

\begin{tabular}{lccc}
\hline Agenda General Description & Non-PE & PE & Difference \\
\hline Elect Director & $80.08 \%$ & $83.77 \%$ & $-3.69 \%^{* * *}$ \\
Amend Omnibus Stock Plan & $5.22 \%$ & $4.53 \%$ & $0.69 \%$ \\
Advisory Vote on Say on Pay Frequency & $2.66 \%$ & $3.70 \%$ & $-1.04 \%$ \\
Ratify X as Auditors & $1.52 \%$ & $0.91 \%$ & $0.61 \%$ \\
Other Business & $1.33 \%$ & $1.21 \%$ & $0.12 \%$ \\
Advisory Vote to Ratify Named Executive & $1.14 \%$ & $2.11 \%$ & $-0.97 \%^{*}$ \\
Officers' Compensation & & & \\
Approve Omnibus Stock Plan & $1.14 \%$ & $0.98 \%$ & $0.16 \%$ \\
\hline$N$ & 1,054 & 1,325 & \\
\hline
\end{tabular}

$* * *, * *, *$ indicate statistical significance at the $0.01,0.05$, and 0.10 levels, respectively, based on two-tailed tests

Panel A presents the results regarding the impact of PE ownership on portfolio firms' financial misreporting.

Columns (1) to (4) report the impact of PE ownership on restatement likelihood, material restatement likelihood, the length of the restated period, and AAER likelihood, respectively. Panel B presents the results regarding the impact of PE firms on portfolio firms' financial misreporting by PE firm size. Columns (1) to (4) report the impact of PE firm size on restatement likelihood, material restatement likelihood, the length of the restated period, and AAER likelihood, respectively. Panel C reports the summary statistics of the board characteristics for PE-backed and nonPE-backed firms. Panel D reports the summary statistics of the vote records for PE-backed and non-PE-backed firms. Panel E reports the dissenting proposal agenda descriptions for PE-backed and non-PE-backed firms by the agenda category. Continuous variables are winsorized at 1 and 99 percent. Absolute $t$ statistics or $z$ statistics are in parentheses, based on standard errors clustered at the firm level. Variables are defined in Appendix A. 
Table 7: Alternative Explanation: Regulatory Attention

\begin{tabular}{|c|c|c|}
\hline Dependent variable & $\begin{array}{c}(1) \\
\text { Restate_SCA }\end{array}$ & $\begin{array}{c}(2) \\
\text { Restate_SEC }\end{array}$ \\
\hline$P E$ & $\begin{array}{r}-1.054 \\
(1.40)\end{array}$ & -0.162 \\
\hline Size & $\begin{array}{l}0.157 \\
(0.53)\end{array}$ & $\begin{array}{l}-0.106 \\
(0.33)\end{array}$ \\
\hline$M T B$ & $\begin{array}{l}0.243 \\
(1.04)\end{array}$ & $\begin{array}{l}0.457^{* *} \\
(2.46)\end{array}$ \\
\hline Lev & $\begin{array}{l}-0.028 \\
(0.45)\end{array}$ & $\begin{array}{l}0.076 \\
(1.19)\end{array}$ \\
\hline$R O A$ & $\begin{array}{l}-0.058 \\
(0.04)\end{array}$ & $\begin{array}{l}5.821 \\
(1.64)\end{array}$ \\
\hline SaleGr & $\begin{array}{l}1.240^{*} \\
(1.68)\end{array}$ & $\begin{array}{l}0.806^{*} \\
(1.79)\end{array}$ \\
\hline Capex & $\begin{array}{l}1.741 \\
(0.47)\end{array}$ & $\begin{array}{l}7.596 \\
(1.31)\end{array}$ \\
\hline Loss & $\begin{array}{l}0.355 \\
(0.91)\end{array}$ & $\begin{array}{l}1.210 \\
(1.53)\end{array}$ \\
\hline Cash & $\begin{array}{l}2.354 \\
(1.55)\end{array}$ & $\begin{array}{l}0.261 \\
(0.13)\end{array}$ \\
\hline Age & $\begin{array}{l}-0.004 \\
(0.40)\end{array}$ & $\begin{array}{c}0.025^{* * * *} \\
(2.65)\end{array}$ \\
\hline$I P O \_A g e$ & $\begin{array}{c}-0.377^{* *} \\
(2.10)\end{array}$ & $\begin{array}{l}0.346 \\
(1.29)\end{array}$ \\
\hline$B i g N$ & $\begin{array}{l}-1.374 \\
(1.48)\end{array}$ & $\begin{array}{c}-2.928^{* * *} \\
(3.06)\end{array}$ \\
\hline NAnalyst & $\begin{array}{l}-0.004 \\
(0.06)\end{array}$ & $\begin{array}{l}0.119 \\
(1.10)\end{array}$ \\
\hline InstOwn & $\begin{array}{l}-0.228 \\
(0.20)\end{array}$ & $\begin{array}{l}0.956 \\
(0.82)\end{array}$ \\
\hline Intercept & $\begin{array}{l}0.683 \\
(0.33)\end{array}$ & $\begin{array}{l}-3.982 \\
(1.58)\end{array}$ \\
\hline Industry FE & Yes & Yes \\
\hline IPO year FE & Yes & Yes \\
\hline Additional Controls & Yes & Yes \\
\hline$N$ & 521 & 521 \\
\hline Pseudo $R^{2}$ & 0.449 & 0.391 \\
\hline
\end{tabular}

$* * *, * * *$ indicate statistical significance at the $0.01,0.05$, and 0.10 levels, respectively, based on two-tailed tests

This table presents the results regarding the impact of PE firms on the likelihood of receiving lawsuits conditional on receiving a restatement. Column (1) shows the impact of PE ownership on the likelihood of getting a securities class action following a restatement. Column (2) shows the impact of PE ownership on the likelihood of getting an SEC investigation following a restatement. Continuous variables are winsorized at 1 and 99 percent. Absolute $z$ statistics are in parentheses, based on standard errors clustered at the firm level. Variables are defined in Appendix A. 
Table 8: Alternative Explanation: Selection Effect

Panel A: Heckman model

\begin{tabular}{|c|c|c|c|c|c|}
\hline Dependent variable & $\begin{array}{l}(1) \\
P E\end{array}$ & $\begin{array}{c}(2) \\
\text { Restatement }\end{array}$ & $\begin{array}{c}(3) \\
\text { Restate_Material }\end{array}$ & $\begin{array}{c}\text { (4) } \\
\text { Restate_Period }\end{array}$ & $\begin{array}{c}(5) \\
A A E R\end{array}$ \\
\hline$P E$ & & $\begin{array}{l}0.502^{* * *} \\
(2.24)\end{array}$ & $\begin{array}{c}0.986^{* * *} \\
(3.14)\end{array}$ & $\begin{array}{l}0.270^{* * * *} \\
(2.82)\end{array}$ & $\begin{array}{l}2.290^{* *} \\
(2.43)\end{array}$ \\
\hline$I M R$ & & $\begin{array}{l}-1.955 \\
(1.25)\end{array}$ & $\begin{array}{l}-1.777 \\
(0.86)\end{array}$ & $\begin{array}{l}-0.942 \\
(1.24)\end{array}$ & $\begin{array}{c}12.216^{*} \\
(1.86)\end{array}$ \\
\hline Size & $\begin{array}{c}0.130^{* * * *} \\
(3.91)\end{array}$ & $\begin{array}{l}0.018 \\
(0.10)\end{array}$ & $\begin{array}{l}-0.218 \\
(1.04)\end{array}$ & $\begin{array}{l}-0.051 \\
(0.60)\end{array}$ & $\begin{array}{c}2.356^{* * * *} \\
(2.80)\end{array}$ \\
\hline$M T B$ & $\begin{array}{l}-0.001 \\
(0.04)\end{array}$ & $\begin{array}{l}0.062 \\
(0.57)\end{array}$ & $\begin{array}{l}0.006 \\
(0.04)\end{array}$ & $\begin{array}{l}0.161^{* * * *} \\
(3.11)\end{array}$ & $\begin{array}{l}0.325 \\
(0.77)\end{array}$ \\
\hline Lev & $\begin{array}{l}0.033^{* *} \\
(2.26)\end{array}$ & $\begin{array}{l}-0.002 \\
(0.06)\end{array}$ & $\begin{array}{l}-0.059 \\
(0.93)\end{array}$ & $\begin{array}{l}0.005 \\
(0.20)\end{array}$ & $\begin{array}{l}0.140 \\
(1.13)\end{array}$ \\
\hline$R O A$ & $\begin{array}{l}0.633^{* *} \\
(2.56)\end{array}$ & $\begin{array}{l}-0.228 \\
(0.22)\end{array}$ & $\begin{array}{l}-0.082 \\
(0.05)\end{array}$ & $\begin{array}{l}-0.301 \\
(0.54)\end{array}$ & $\begin{array}{l}3.619 \\
(0.51)\end{array}$ \\
\hline SaleGr & $\begin{array}{c}-0.208^{* * * *} \\
(2.73)\end{array}$ & $\begin{array}{l}0.354 \\
(0.79)\end{array}$ & $\begin{array}{l}0.651 \\
(1.49)\end{array}$ & $\begin{array}{l}-0.050 \\
(0.32)\end{array}$ & $\begin{array}{l}-1.785 \\
(1.15)\end{array}$ \\
\hline Capex & $\begin{array}{r}-1.062^{*} \\
(1.66)\end{array}$ & $\begin{array}{l}0.992 \\
(0.55)\end{array}$ & $\begin{array}{l}-0.516 \\
(0.17)\end{array}$ & $\begin{array}{l}0.549 \\
(0.52)\end{array}$ & $\begin{array}{l}-5.583 \\
(0.74)\end{array}$ \\
\hline Loss & $\begin{array}{l}0.033 \\
(0.36)\end{array}$ & $\begin{array}{l}0.519^{* *} \\
(2.56)\end{array}$ & $\begin{array}{l}0.318 \\
(1.07)\end{array}$ & $\begin{array}{l}-0.042 \\
(0.36)\end{array}$ & $\begin{array}{l}0.508 \\
(0.47)\end{array}$ \\
\hline Cash & $\begin{array}{c}-1.697^{* * * *} \\
(5.34)\end{array}$ & $\begin{array}{l}3.227 \\
(1.63)\end{array}$ & $\begin{array}{l}3.688 \\
(1.60)\end{array}$ & $\begin{array}{l}1.750 \\
(1.63)\end{array}$ & $\begin{array}{c}-11.188 \\
(1.34)\end{array}$ \\
\hline Age & & $\begin{array}{l}-0.001 \\
(0.33)\end{array}$ & $\begin{array}{l}-0.001 \\
(0.17)\end{array}$ & $\begin{array}{l}-0.002 \\
(0.89)\end{array}$ & $\begin{array}{l}-0.030 \\
(1.56)\end{array}$ \\
\hline IPO_Age & & $\begin{array}{l}-0.104 \\
(1.44)\end{array}$ & $\begin{array}{l}-0.036 \\
(0.34)\end{array}$ & $\begin{array}{l}-0.014 \\
(0.29)\end{array}$ & $\begin{array}{l}-0.540^{*} \\
(1.74)\end{array}$ \\
\hline$B i g N$ & & $\begin{array}{l}-0.178 \\
(0.46)\end{array}$ & $\begin{array}{c}-1.207^{* * * *} \\
(2.61)\end{array}$ & $\begin{array}{l}-0.083 \\
(0.62)\end{array}$ & $\begin{array}{l}-0.127 \\
(0.07)\end{array}$ \\
\hline NAnalyst & & $\begin{array}{l}-0.064^{* * *} \\
(2.13)\end{array}$ & $\begin{array}{l}0.020 \\
(0.57)\end{array}$ & $\begin{array}{l}0.012 \\
(0.87)\end{array}$ & $\begin{array}{l}-0.015 \\
(0.09)\end{array}$ \\
\hline InstOwn & & $\begin{array}{l}0.855^{* *} \\
(2.13)\end{array}$ & $\begin{array}{l}0.287 \\
(0.58)\end{array}$ & $\begin{array}{l}-0.325^{*} \\
(1.77)\end{array}$ & $\begin{array}{c}6.979^{* * *} \\
(2.14)\end{array}$ \\
\hline Intercept & $\begin{array}{c}-1.743^{*} \\
(1.81)\end{array}$ & $\begin{array}{l}1.093 \\
(0.34)\end{array}$ & $\begin{array}{l}3.218 \\
(0.78)\end{array}$ & $\begin{array}{l}-0.716 \\
(7.38)\end{array}$ & $\begin{array}{c}-39.122^{* * * *} \\
(2.95)\end{array}$ \\
\hline Industry FE & Yes & Yes & Yes & Yes & Yes \\
\hline IPO year FE & Yes & Yes & Yes & Yes & Yes \\
\hline Additional Controls & No & Yes & Yes & Yes & Yes \\
\hline$N$ & 3,146 & 3,146 & 3,146 & 521 & 3,146 \\
\hline Pseudo/Adjusted $R^{2}$ & 0.287 & 0.171 & 0.196 & 0.398 & 0.499 \\
\hline
\end{tabular}


Panel B: Instrumental variable

\begin{tabular}{|c|c|c|c|c|c|}
\hline Dependent variable & $\begin{array}{l}\text { (1) } \\
P E\end{array}$ & $\begin{array}{c}(2) \\
\text { Restatement }\end{array}$ & $\begin{array}{c}(3) \\
\text { Restate_Material }\end{array}$ & $\begin{array}{c}(4) \\
\text { Restate_Period }\end{array}$ & $\begin{array}{c}(5) \\
A A E R\end{array}$ \\
\hline PE_Ratio & $\begin{array}{l}0.854^{* * * *} \\
(39.30)\end{array}$ & & & & \\
\hline$P E \_I V$ & & $\begin{array}{l}0.440^{* * * *} \\
(3.73)\end{array}$ & $\begin{array}{c}0.757^{* * * *} \\
(5.51)\end{array}$ & $\begin{array}{l}0.256^{* *} \\
(2.12)\end{array}$ & $\begin{array}{c}1.071^{* * * *} \\
(3.06)\end{array}$ \\
\hline Size & $\begin{array}{l}0.002 \\
(0.23)\end{array}$ & $\begin{array}{c}0.088^{* *} \\
(1.98)\end{array}$ & $\begin{array}{l}-0.038 \\
(0.78)\end{array}$ & $\begin{array}{l}0.024 \\
(0.45)\end{array}$ & $\begin{array}{c}0.611^{* * * *} \\
(3.95)\end{array}$ \\
\hline$M T B$ & $\begin{array}{l}0.003 \\
(0.63)\end{array}$ & $\begin{array}{l}0.027 \\
(0.51)\end{array}$ & $\begin{array}{l}0.008 \\
(0.15)\end{array}$ & $\begin{array}{c}0.160^{* * * *} \\
(3.36)\end{array}$ & $\begin{array}{l}0.173 \\
(1.48)\end{array}$ \\
\hline Lev & $\begin{array}{l}0.005^{*} \\
(1.85)\end{array}$ & $\begin{array}{l}0.021 \\
(1.53)\end{array}$ & $\begin{array}{l}-0.009 \\
(0.43)\end{array}$ & $\begin{array}{l}0.023 \\
(1.16)\end{array}$ & $\begin{array}{l}-0.017 \\
(0.45)\end{array}$ \\
\hline$R O A$ & $\begin{array}{l}0.078^{* *} \\
(2.28)\end{array}$ & $\begin{array}{l}0.380 \\
(1.19)\end{array}$ & $\begin{array}{l}0.378 \\
(1.15)\end{array}$ & $\begin{array}{l}0.070 \\
(0.14)\end{array}$ & $\begin{array}{c}-2.061^{\text {**** }} \\
(2.76)\end{array}$ \\
\hline SaleGr & $\begin{array}{c}-0.022^{*} \\
(1.74)\end{array}$ & $\begin{array}{l}0.012 \\
(0.06)\end{array}$ & $\begin{array}{l}0.276 \\
(1.38)\end{array}$ & $\begin{array}{l}-0.172 \\
(1.62)\end{array}$ & $\begin{array}{l}-0.092 \\
(0.22)\end{array}$ \\
\hline Capex & $\begin{array}{c}-0.356^{* * *} \\
(2.65)\end{array}$ & $\begin{array}{l}-0.111 \\
(0.19)\end{array}$ & $\begin{array}{l}-0.618 \\
(0.74)\end{array}$ & $\begin{array}{l}-0.057 \\
(0.07)\end{array}$ & $\begin{array}{l}1.050 \\
(0.45)\end{array}$ \\
\hline Loss & $\begin{array}{l}0.010 \\
(0.58)\end{array}$ & $\begin{array}{l}0.311^{* * * *} \\
(2.95)\end{array}$ & $\begin{array}{l}0.186 \\
(1.52)\end{array}$ & $\begin{array}{l}-0.027 \\
(0.25)\end{array}$ & $\begin{array}{l}-0.195 \\
(0.56)\end{array}$ \\
\hline Cash & $\begin{array}{c}-0.187^{* * * *} \\
(4.44)\end{array}$ & $\begin{array}{l}0.525^{*} \\
(1.73)\end{array}$ & $\begin{array}{l}0.915^{* * * *} \\
(2.72)\end{array}$ & $\begin{array}{l}0.552 \\
(1.35)\end{array}$ & $\begin{array}{c}2.557^{* * * * *} \\
(3.14)\end{array}$ \\
\hline Age & $\begin{array}{l}-0.000 \\
(0.10)\end{array}$ & $\begin{array}{l}-0.001 \\
(0.52)\end{array}$ & $\begin{array}{l}-0.001 \\
(0.55)\end{array}$ & $\begin{array}{l}-0.002 \\
(0.93)\end{array}$ & $\begin{array}{l}-0.006 \\
(1.02)\end{array}$ \\
\hline IPO_Age & $\begin{array}{c}-0.019^{* * * *} \\
(5.68)\end{array}$ & $\begin{array}{l}-0.062 \\
(1.62)\end{array}$ & $\begin{array}{l}-0.025 \\
(0.53)\end{array}$ & $\begin{array}{l}-0.015 \\
(0.34)\end{array}$ & $\begin{array}{c}-0.267^{* *} \\
(2.13)\end{array}$ \\
\hline$B i g N$ & $\begin{array}{c}0.119^{* * * *} \\
(4.84)\end{array}$ & $\begin{array}{l}-0.144 \\
(0.94)\end{array}$ & $\begin{array}{c}-0.685^{\text {**** }} \\
(3.95)\end{array}$ & $\begin{array}{l}-0.109 \\
(0.90)\end{array}$ & $\begin{array}{l}-0.030 \\
(0.06)\end{array}$ \\
\hline NAnalyst & $\begin{array}{l}0.001 \\
(0.53)\end{array}$ & $\begin{array}{l}-0.030^{* * *} \\
(2.57)\end{array}$ & $\begin{array}{l}0.013 \\
(0.96)\end{array}$ & $\begin{array}{l}0.013 \\
(0.98)\end{array}$ & $\begin{array}{l}-0.017 \\
(0.41)\end{array}$ \\
\hline InstOwn & $\begin{array}{l}-0.052 \\
(1.64)\end{array}$ & $\begin{array}{c}0.508^{* * * *} \\
(3.02)\end{array}$ & $\begin{array}{l}0.153 \\
(0.79)\end{array}$ & $\begin{array}{c}-0.306^{*} \\
(1.78)\end{array}$ & $\begin{array}{c}2.992^{* * * *} \\
(5.65)\end{array}$ \\
\hline Intercept & $\begin{array}{r}-0.052 \\
(0.59) \\
\end{array}$ & $\begin{array}{c}-1.621^{* * *} \\
(2.62) \\
\end{array}$ & $\begin{array}{l}-0.365 \\
(0.52) \\
\end{array}$ & $\begin{array}{l}5.304^{* * * *} \\
(14.40)\end{array}$ & $\begin{array}{c}-8.178^{* * * *} \\
(6.70) \\
\end{array}$ \\
\hline Industry FE & Yes & Yes & Yes & Yes & Yes \\
\hline IPO year FE & Yes & Yes & Yes & Yes & Yes \\
\hline Additional Controls & Yes & Yes & Yes & Yes & Yes \\
\hline$N$ & 3,146 & 3,146 & 3,146 & 521 & 3,146 \\
\hline Adjusted $R^{2}$ & 0.668 & N/A & N/A & 0.398 & N/A \\
\hline
\end{tabular}

$* * *, * *, *$ indicate statistical significance at the $0.01,0.05$, and 0.10 levels, respectively, based on two-tailed tests

Panel A presents the results regarding the impact of PE firms on portfolio firms' financial misreporting controlling for the selection effect using the Heckman model (1979). Column (1) reports the first-stage results. Columns (2) to (5) report the second-stage results, including the impact of PE sponsorship on restatement likelihood, material restatement likelihood, the length of the restated period, and AAER likelihood, respectively. Panel B presents the results of 2SLS regression regarding the impact of PE firms on portfolio firms' financial misreporting, using the ratio of PE-backed IPOs to all IPOs in the same industry and IPO year as an instrumental variable for PE sponsorship. Column (1) reports the first-stage results. Columns (2) to (5) report the second-stage results, including the impact of PE sponsorship on restatement likelihood, material restatement likelihood, the length of the restated period, and AAER likelihood, respectively. Continuous variables are winsorized at 1 and 99 percent. Absolute $t$ statistics or $z$ statistics are in parentheses, based on standard errors clustered at the firm level. Variables are defined in Appendix A. 
Table 9: Reconciliation with Katz (2009)

\begin{tabular}{|c|c|c|c|c|c|}
\hline Dependent variable & $\begin{array}{c}(1) \\
D \_W A C C_{-} M D D\end{array}$ & $\begin{array}{c}(2) \\
D \_W A C C_{-} B S\end{array}$ & $\begin{array}{c}(3) \\
D \_W A C C_{-} P M\end{array}$ & $\begin{array}{c}(4) \\
C h \_E m p\end{array}$ & $\begin{array}{c}\text { (5) } \\
\text { GrLTNOA }\end{array}$ \\
\hline$P E$ & $\begin{array}{c}-0.009^{* *} \\
(2.31)\end{array}$ & $\begin{array}{l}-0.002 \\
(0.65)\end{array}$ & $\begin{array}{c}-0.011^{* *} \\
(1.97)\end{array}$ & $\begin{array}{c}-0.046^{* *} \\
(2.41)\end{array}$ & $\begin{array}{c}-0.037^{* * *} \\
(3.50)\end{array}$ \\
\hline Size & $\begin{array}{c}-0.005^{* *} \\
(2.48)\end{array}$ & $\begin{array}{c}-0.004^{* * * *} \\
(2.65)\end{array}$ & $\begin{array}{l}-0.003 \\
(1.25)\end{array}$ & $\begin{array}{l}0.002 \\
(0.23)\end{array}$ & $\begin{array}{l}0.005 \\
(1.06)\end{array}$ \\
\hline$M T B$ & $\begin{array}{c}-0.005^{* * *} \\
(2.03)\end{array}$ & $\begin{array}{l}0.002 \\
(1.11)\end{array}$ & $\begin{array}{c}-0.008^{* * * *} \\
(2.64)\end{array}$ & $\begin{array}{l}0.008 \\
(0.91)\end{array}$ & $\begin{array}{l}0.003 \\
(0.70)\end{array}$ \\
\hline Lev & $\begin{array}{l}0.000 \\
(0.42)\end{array}$ & $\begin{array}{l}0.000 \\
(0.44)\end{array}$ & $\begin{array}{l}0.001 \\
(0.91)\end{array}$ & $\begin{array}{l}-0.003 \\
(1.39)\end{array}$ & $\begin{array}{c}-0.003^{* *} \\
(2.09)\end{array}$ \\
\hline$R O A$ & $\begin{array}{l}0.037^{* * *} \\
(2.07)\end{array}$ & $\begin{array}{c}0.061^{* * * *} \\
(3.34)\end{array}$ & $\begin{array}{l}0.049^{* * *} \\
(2.05)\end{array}$ & $\begin{array}{l}-0.049 \\
(0.54)\end{array}$ & $\begin{array}{c}0.240^{* * * * *} \\
(3.34)\end{array}$ \\
\hline SaleGr & $\begin{array}{l}0.007^{* *} \\
(2.20)\end{array}$ & $\begin{array}{l}-0.000 \\
(0.05)\end{array}$ & $\begin{array}{l}0.002 \\
(0.28)\end{array}$ & $\begin{array}{c}0.308^{* * * *} \\
(6.15)\end{array}$ & $\begin{array}{c}0.113^{* * * *} \\
(5.60)\end{array}$ \\
\hline Capex & $\begin{array}{l}-0.037 \\
(1.33)\end{array}$ & $\begin{array}{l}-0.015 \\
(0.60)\end{array}$ & $\begin{array}{l}-0.005 \\
(0.13)\end{array}$ & $\begin{array}{l}-0.215 \\
(1.15)\end{array}$ & $\begin{array}{c}0.386^{* * *} \\
(3.87)\end{array}$ \\
\hline Loss & $\begin{array}{c}-0.009^{*} \\
(1.88)\end{array}$ & $\begin{array}{c}-0.011^{* * * *} \\
(2.99)\end{array}$ & $\begin{array}{l}-0.003 \\
(0.49)\end{array}$ & $\begin{array}{l}-0.007 \\
(0.25)\end{array}$ & $\begin{array}{c}-0.040^{* *} \\
(2.55)\end{array}$ \\
\hline Cash & $\begin{array}{c}-0.046^{* * *} \\
(2.94)\end{array}$ & $\begin{array}{l}-0.011 \\
(0.84)\end{array}$ & $\begin{array}{c}-0.071^{* * *} \\
(3.80)\end{array}$ & $\begin{array}{l}-0.144 \\
(1.35)\end{array}$ & $\begin{array}{l}-0.082^{*} \\
(1.73)\end{array}$ \\
\hline Age & $\begin{array}{c}-0.000^{* *} \\
(2.10)\end{array}$ & $\begin{array}{l}-0.000 \\
(0.72)\end{array}$ & $\begin{array}{l}-0.000 \\
(1.45)\end{array}$ & $\begin{array}{c}-0.001^{* * * *} \\
(3.32)\end{array}$ & $\begin{array}{c}-0.001^{* * * *} \\
(3.14)\end{array}$ \\
\hline IPO_Age & $\begin{array}{l}0.000 \\
(0.20)\end{array}$ & $\begin{array}{l}-0.001 \\
(1.14)\end{array}$ & $\begin{array}{l}-0.002 \\
(1.05)\end{array}$ & $\begin{array}{c}-0.034^{* * * *} \\
(2.85)\end{array}$ & $\begin{array}{c}-0.014^{* *} \\
(2.53)\end{array}$ \\
\hline$B i g N$ & $\begin{array}{l}-0.006 \\
(0.94)\end{array}$ & $\begin{array}{l}-0.007 \\
(1.09)\end{array}$ & $\begin{array}{l}-0.010 \\
(1.30)\end{array}$ & $\begin{array}{l}0.039 \\
(1.46)\end{array}$ & $\begin{array}{l}-0.015 \\
(0.87)\end{array}$ \\
\hline Intercept & $\begin{array}{c}0.072^{* * *} \\
(3.68)\end{array}$ & $\begin{array}{c}0.046^{* * * *} \\
(3.04)\end{array}$ & $\begin{array}{c}0.075^{* * * *} \\
(2.89)\end{array}$ & $\begin{array}{c}0.237^{* * *} \\
(3.24)\end{array}$ & $\begin{array}{l}0.060 \\
(1.43)\end{array}$ \\
\hline Industry FE & Yes & Yes & Yes & Yes & Yes \\
\hline IPO year FE & Yes & Yes & Yes & Yes & Yes \\
\hline$N$ & 2,114 & 2,213 & 2,115 & 3,146 & 3,146 \\
\hline Adjusted $R^{2}$ & 0.101 & 0.126 & 0.073 & 0.231 & 0.268 \\
\hline
\end{tabular}

$* * *, * * *$ indicate statistical significance at the $0.01,0.05$, and 0.10 levels, respectively, based on two-tailed tests

This table presents a replication of Katz (2009) using a sample of IPO firms that went public between 1998 and 2015. Columns (1) to (3) show the impact of PE sponsorship on discretionary accruals. Columns (4) and (5) show the impact of PE sponsorship on growth. Continuous variables are winsorized at 1 and 99 percent. Absolute $t$ statistics are in parentheses, based on standard errors clustered at the firm level. Variables are defined in Appendix A. 